\title{
Forage options to sustainably intensify smallholder farming systems on tropical sandy soils. A review
}

\author{
Joshua N. M. Philp ${ }^{1} \cdot$ Wendy Vance ${ }^{2} \cdot$ Richard W. Bell $^{2} \cdot$ Ty Chhay $^{3} \cdot$ Davina Boyd $^{2}$. \\ Viengsavanh Phimphachanhvongsod ${ }^{4} \cdot$ Matthew D. Denton $^{1}$
}

Accepted: 10 April 2019 / Published online: 6 May 2019

(C) INRA and Springer-Verlag France SAS, part of Springer Nature 2019

\begin{abstract}
Intensifying livestock production by integrating perennial forages has great potential to contribute to sustainable development and livelihoods in the Mekong region. However, the approach taken must be informed by the environmental, social, and cultural context of the region. Accordingly, we review published research papers and reports from relevant research for development projects to identify options for sustainably integrating forages into farming systems, with a focus on sand-dominant soils of southern Laos and Cambodia. First, we examine existing livestock management practices to determine the compatibility of forages as an option to intensify livestock production. Second, we review the environmental properties of rainfed lowland rice systems with sandy soils and their implications for forage growing. Third, we identify and compare the suitability of existing forage genetics that is adapted to these environmental properties. Fourth, we propose adapted varieties, outline appropriate management options, and discuss the sustainable engagement of smallholders in the production of forages. The key findings are as follows: (1) Forages appear compatible with the sociocultural properties of smallholder farming systems in southern Laos and Cambodia because there is an awareness of existing limitations to livestock production, widespread desire to possess livestock for cultural reasons, and mounting pressure to improve the productivity of grazing areas and the efficiency of labor. (2) The limiting properties of the environment are drought, soil acidity, flooding, and soil infertility, which must be addressed in the selection and management of forage genetics. (3) Broadly adapted perennial tropical grasses and herbaceous legumes exist, but these are unlikely to thrive in lowland ecosystems of southern Laos and Cambodia that are prone to both annual flooding and drought. (4) Variations in surface hydrology at the farm scale often result in differentiated environments suitable for differing varieties. Brachiaria sp. hybrid "Mulato II," Panicum maximum, and Stylosanthes guianensis are recommended for droughtprone, acidic sands that are safe from prolonged submergence and would require the least additional management, whilst Paspalum atratum is recommended for low-lying areas with access to irrigation. (5) The transition to perennial forage integration appears to be accessible to farmers and can allow them to rapidly accumulate benefits in terms of saved labor; however, efforts to intensify animal production have been slow and must contend with multiple challenges: poor understanding of animal husbandry and health, cultural views relating to the role of animals in production systems, and poor access to forage and livestock services. These must all be addressed if sustainably intensified animal production is to be achieved in these and similar regions.
\end{abstract}

Keywords Acid soils $\cdot$ Cambodia $\cdot$ Laos $\cdot$ Livestock $\cdot$ Mekong region $\cdot$ Rural development $\cdot$ Sustainable intensification $\cdot$ Tropical agriculture $\cdot$ Tropical grasslands

Matthew D. Denton

matthew.denton@adelaide.edu.au

1 School of Agriculture, Food and Wine, The University of Adelaide, Adelaide, Australia

2 Agriculture Discipline, College of Science, Health, Engineering and Education, Murdoch University, Perth, Australia
3 Centre for Livestock and Agricultural Development, Phnom Penh, Cambodia

4 National Agriculture and Forestry Research Institute, Ministry of Agriculture and Forestry, Vientiane, Lao People's Democratic Republic 


\section{Contents}

1. Introduction

2. Sociocultural compatibility and economic feasibility of forage growing

2.1 The nature and role of livestock management in southern Laos and Cambodia

2.2 Demand for forage technologies

2.3 Economic and sociocultural compatibility of forage growing

3. Land and water resources in rainfed lowland production systems of southern Laos and Cambodia

3.1 Climate

3.2 Soil

3.3 Implications of climate and soil resources for forage production

4. Available forage germplasm adapted to southern Laos and Cambodia

4.1 Adapted varieties for southern Laos and Cambodia

4.2 Other traits affecting compatibility with farming systems

4.3 Availability of adapted varieties

5. Developing compatible forage options for southern

Laos and Cambodia

5.1 Management of drought

5.2 Management of soil acidity

5.3 Management of soil nutrition

5.4 Management of flooding

5.5 Forage niches

5.6 Additional requirements for sustainably intensifying animal production with forages

6. Conclusion

Acknowledgments

References

\section{Introduction}

Agricultural production on sand-textured soils of Cambodia and the Lao PDR is characterized by a high involvement of each nation's poorest and most food-insecure peoples, whose livelihoods are typically reliant on rainfed, low-input rice production (Fig. 1), and limited livestock keeping. The intensification of livestock production by vulnerable households has the potential to improve their profitability and resilience; however, inadequate feed quality and quantity have consistently been identified as major constraints to livestock production in Southeast Asia for more than 15 years of research (Devendra and Sevilla 2002; Bush et al. 2014b). The integration of perennial forages has been widely researched and demonstrated to be a pathway to sustainably improve the supply of feed for supporting increased livestock production in Southeast Asia (Stür et al. 2013; White et al. 2013; Bell et al. 2015; Rudel et al. 2015).

The benefits achieved by growing forages for feeding livestock in smallholder farming systems of Southeast Asia are

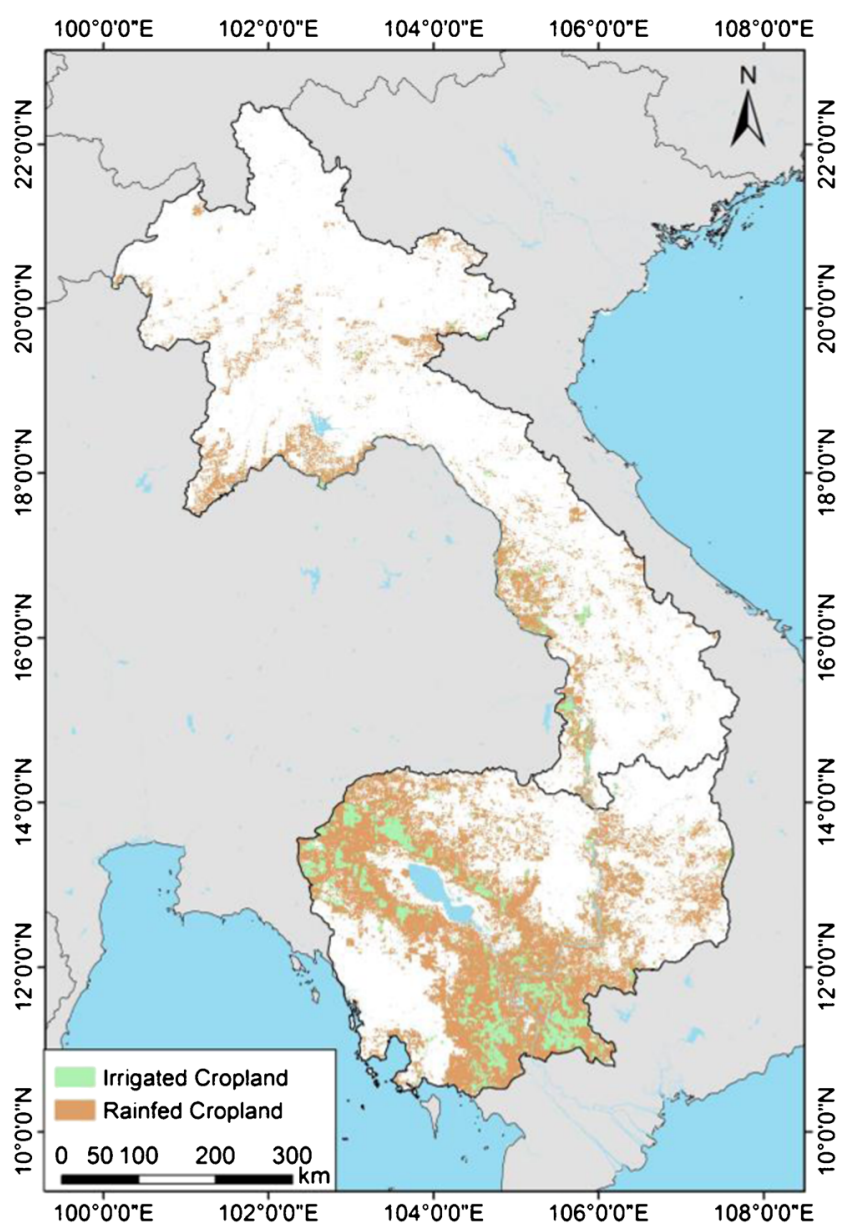

Fig. 1 Map of rainfed and irrigated cropland distribution in Cambodia and Laos. GIS data adapted from Teluguntla et al. (2016)

numerous and well-documented in the literature (Peters et al. 2001; Millar and Photakoun 2008; Stür et al. 2013). Foremost, growing forages provide households with a general increase in the quantity and quality of feeds available for animal production (Fig. 2) that can generate greater returns from livestock than would be attainable under traditional smallholder farming practices (Peters et al. 2001). Additionally, through techniques such as silage making and the selection of drought-tolerant varieties, forages can provide more nutritious feed into the dry season, when livestock are otherwise typically fed low-quality roughages such as rice straw. Supplementing low-quality roughages with nutritious forages during feed deficits has been shown to increase the utilization of those roughages by ruminants (Philp et al. 2016) and improve feed use efficiency during compensatory growth after feed deficits (Philp et al. 2017). The market advantage of supplying well-conditioned animals, during a period in which many farmers in the same area only have a poor condition or unhealthy animals to offer, quickly translates into economic benefits of up to $80 \%$ higher price offers from traders (Tiemann et al. 2014b). Second, the high time and labor inputs of traditional livestock feeding practices can also be reduced by growing forages (Stür et al. 2007). Forages can be planted to 


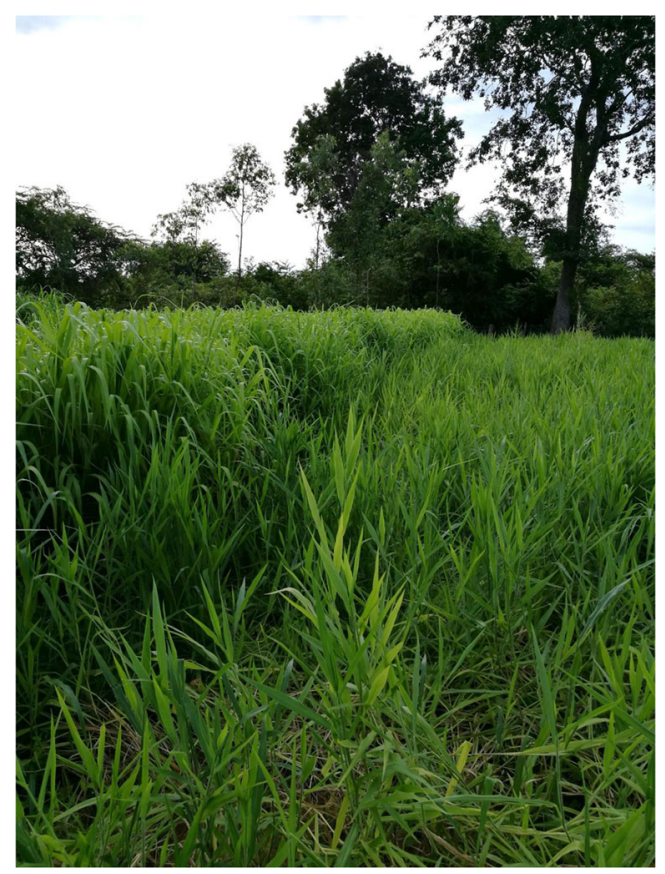

Fig. 2 A highly productive forage field featuring Panicum maximum (left) and Brachiaria ruziziensis (right) in Salavan Province, the Lao PDR

provide accessible feed in controlled locations (Stür et al. 2002) and may have morphological traits that increase the ease of harvesting compared with uncultivated grasslands, significantly reducing the labor required to feed livestock (Dimang et al. 2009; Maxwell et al. 2012). Labor savings are more pronounced after initial establishment because planting is unnecessary in subsequent years. Typical labor savings of $2 \mathrm{~h}$ per day have been reported in Cambodia (Bush et al. 2014b) and Laos (Tiemann et al. 2014b), but may be more than $7 \mathrm{~h}$ per day, which can significantly impact social and economic development (Dimang et al. 2009). Third, ecological benefits can be attained by growing forages. Deep-rooted perennial forages limit soil erosion and can sequester an estimated 4-14 $t$ of carbon per hectare in the top $1 \mathrm{~m}$ of the soil profile each year (Fisher et al. 1994), and leguminous forages may also fix atmospheric nitrogen, thereby increasing soil fertility (Rao et al. 2015). Perennial crops reduce the need for tillage and contribute residues, both of which can improve the physical, chemical, and biological properties of tropical acid soils (Lienhard et al. 2013). Confined feeding practices made possible by convenient placement of planted forages also concentrate manure so that is more easily managed to improve soil fertility (Stür et al. 2002, 2007; Tiemann et al. 2014b).

The combined benefits of integrating forages into rainfed rice production systems have been demonstrated to be a strong motivation for farmers to retain the technology after adoption (Bush et al. 2014b). Despite this, the overall adoption of forages in farming systems on sandy soils in Cambodia and Laos remains low (Millar and Photakoun 2008; Tiemann et al. 2014b). Environmental, social, cultural, and economic properties of target systems can limit the attractiveness and utility of technology to farmers, therefore the technology offered must be compatible with those same properties (Sumberg 2002).

This paper reviews the properties of farming systems on sandtextured soils of Cambodia and the Lao PDR that determine the compatibility and feasibility of integrating perennial forages as a pathway for sustainably intensifying livestock production. Internal and gray literature originating from completed research for development projects in Cambodia and Laos were accessed to complement the published material cited. This literature is critical for raising awareness of the operational considerations that determine the compatibility of agricultural interventions, particularly in heterogeneous smallholder environments. There are four main components of this review: (1) examining existing livestock management practices to determine the compatibility of forages as an option to intensify livestock production, (2) reviewing the environmental properties of rainfed lowland rice systems with sandy soils and the implications they have for production, (3) identifying and comparing the suitability of existing forage varieties, and (4) synthesizing compatible options for the sustainable integration of forages into existing systems based on appropriate varieties, attainable management options, and engagement strategies identified throughout the review.

\section{Sociocultural compatibility and economic feasibility of forage growing}

Sociocultural compatibility refers to the factors that influence how individuals and groups value a technology, including existing attitudes, norms, and priorities (Ojiem et al. 2006). These are substantive determinants of the feasibility and acceptance of an introduced technology such as forage integration.

\subsection{The nature and role of livestock management in southern Laos and Cambodia}

Intensive production and trading are rarely practiced amongst households that keep livestock (Lefroy et al. 2010; Bush et al. 2014a). Instead, large livestock, particularly cattle and buffalo, are kept primarily as assets that are used to finance expected and unexpected future costs including healthcare, education, and weddings, especially where households are not fully integrated into credit markets (Millar and Photakoun 2008; Lefroy et al. 2010; Bush et al. 2014b). Additionally, livestock may provide draught power, manure, cultural value, and a significant portion of cash income (Millar and Photakoun 2008; Pen et al. 2010; Nampanya et al. 2012). Increasing mechanization of agriculture in the region has resulted in a reduction in the number of animals required for draught power but may present an opportunity to place greater emphasis on profit-driven livestock production (Fukai and Ouk 2012; Tiemann et al. 2014a). 
Inadequate provision of feed quality and quantity is a major constraint to cattle and buffalo production in both Cambodia and the Lao PDR (Bush et al. 2014a). Large ruminant livestock in the lowlands of both countries typically have their movements controlled or restricted in the wet season to avoid damaging crops, with rice straw being the primary feed supplement for cattle, despite its limited nutritional value (Bush et al. 2014a). After rice is harvested at the end of the wet season, cattle are typically able to graze on the stubbles, rangeland, or roadside vegetation. Lowland areas include only $24.1 \%$ of all defined grazing areas in the Lao PDR, and most cattle are grazed in, or fed from, various extensive yet unproductive ecosystems, including many with sandy soil (Phimphachanhvongsod and Phengsavanh 1998; Bush et al. 2014b). In Cambodia, grazing resources are of a similarly poor nutritional quality (Nampanya et al. 2012), and animal condition is often lost in both countries as a result of reliance on low-quality feed in the dry season. Despite their low productivity, the traditional practices are still labor-intensive, with herding animals reported to occupy up to 8 person-hours per day, with the task often allocated to children (Dimang et al. 2009; Bush et al. 2014b). This limits the time and labor available for other farm and household activities, off-farm employment, and education (Millar and Photakoun 2008; Dimang et al. 2009; Maxwell et al. 2012). Overall, these circumstances result in poor condition and sale value, decreased reproduction, increased susceptibility to disease amongst animals, and a high demand for household labor (Bush et al. 2014b).

Participatory diagnosis throughout Southeast Asia has indicated that farmers are aware of labor and animal feeding constraints in their enterprises (Stür et al. 2002; Pen et al. 2010). Previous research in Southeast Asia under similar circumstances has shown that these constraints can be effectively reduced by integrating forages into existing farming systems (Peters et al. 2001; Millar and Connell 2010). However, many farmers who have not been directly involved with foragerelated interventions are unaware of forage growing as a solution to these constraints (Bush et al. 2014b).

\subsection{Demand for forage technologies}

Farmer interest in managing a large area of highly productive grassland has been found to vary, based on the quality and quantity of existing grazing resources available to them (Phimphachanhvongsod and Phengsavanh 1998; Tiemann et al. 2014b). During a recent study in southern Laos, the greatest interest in growing improved forages occurred where traditional grazing areas were both small and of low quality, because no alternative usage options exist for these lands (Tiemann et al. 2014b). Conversely, in less developed areas where farmers had access to larger expanses of native vegetation, or current access to government-owned forests, the establishment of a forage-based feeding system was reported to be less attractive to farmers, even though these grasslands were of a poor nutritional quality, required more labor to use, and could only support low stocking rates (Tiemann et al. 2014b). In these circumstances, it has been suggested that farmers are too preoccupied with supporting their fragile livelihoods and are unwilling to risk disruptions to arrangements that are tolerable to them, despite the poor productivity of their animals (Phimphachanhvongsod and Phengsavanh 1998). The challenge of providing farmers with attractive options to invest in improved forages when they have abundant but low-quality feed resources has been investigated by Bush et al. (2014b), who found that lowland rice farmers in Cambodia became enthusiastic about adopting forage growing after being exposed to the benefits of doubled cattle live weights and reduced labor inputs. Interventions that encourage farmers to adopt forage growing are therefore more likely to be compatible when they generate a rapid and noticeable positive impact on the common concerns of farmers (Millar and Connell 2010).

Changes in the accessibility of existing land and labor resources may also encourage farmers to consider alternative practices such as forage growing. Land use change arising from new developments, resettlements, changes in government policy, or the opening up of new farmland may induce pressure on farmers to improve forage production to support higher stocking rates, as access to natural grassland is reduced (Tiemann et al. 2014b). Earlier research in southern Laos has explored the enhancement of existing communal grasslands by introducing legumes and various slashing treatments; however, this has reportedly met with limited success relative to the practice of fully cultivating smaller areas around villages with improved forages such as Brachiaria decumbens and Stylosanthes guianensis (Hacker et al. 1998). Furthermore, it has been reported that farmers in Laos preferred to manage forages that belonged to individual households, rather than communal plots that were prone to exploitation or neglect arising from lack of perceived ownership (Phimphachanhvongsod and Phengsavanh 1998).

The cultivation of new forage areas on farms has the potential to create competition for land use where holdings are small. Although only 500 to $1000 \mathrm{~m}^{2}$ of improved perennial grass is required per head of cattle for farmers to begin accruing productivity and labor benefits (Stür et al. 2007; Ba et al. 2013), the majority of poor farmers prioritize rice production for cultural and food security reasons (Millar and Photakoun 2008; Tiemann et al. 2014b) and may be reluctant to change practice. Therefore, farmers must perceive the value of forage to outweigh the cost as defined by the cultural framework within which they operate, if they are to divert their privately owned resources from it (Ojiem et al. 2006). Perception of the value of integrating forages is likely to vary greatly over a small spatial scale because individual priorities are shaped by the heterogeneous endowment of experiences, resources, and beliefs of individual households. Previous research with forage adopters in Cambodia has shown that forage production can be perceived as worthwhile, particularly by households motivated by the desire to save labor (Fukai 
and Ouk 2012; Bush et al. 2014b: Manivong et al. 2014; Ashley et al. 2018b). Furthermore, labor availability for all farm activities is declining in many smallholder farms in Cambodia and Laos due to outmigration for paid employment. Although the initial establishment of perennial forages is labor-intensive, requiring land preparation, planting, and the prevention of unwanted access by roaming livestock (Tiemann et al. 2014b), planting forages as an alternative to transplanted paddy rice would represent an immediate labor saving per unit of area. Land preparation and sowing of forages are comparable in technique and effort to broadcasting paddy rice in furrows, which has been estimated not to exceed 5 person-days per hectare (Fukai and Ouk 2012), considerably lower than the estimated 25 to 50 person-days per hectare required for transplanting paddy rice (Dawe 2005). Establishment could also coincide with wet season paddy rice planting and would not likely represent a significant disruption to existing annual household labor arrangements (Ashley et al. 2018b).

\subsection{Economic and sociocultural compatibility of forage growing}

Smallholder farmers that are able to improve and sustainably intensify animal production may be able to capitalize on rapidly growing markets for animal products locally and in China, Thailand, and Vietnam (Millar and Photakoun 2008; Stür et al. 2013). Examples of smallholder farmers being empowered by forage growing to increase their interaction with the regional cash economy are widely reported in the literature, including studies from lowland rice ecosystems of Cambodia and Laos (Bush et al. 2014a, 2014b), and other countries such as China, Indonesia, Vietnam, and the Philippines, where livestock traditionally fulfill similar sociocultural and economic functions in smallholder systems (Young et al. 2014). Although there is an increasing number of farmers raising livestock for breeding and sale (Samkol et al. 2015), many are still limited by access issues, poorly developed markets, and supply-side issues. Previously, a participatory, systems-oriented innovation process which linked rural traders to urban markets that demanded younger, heavier animals, achieved a total transformation of rural animal production from traditional grazing to stall-fed, high quality beef production in Ea Kar, Vietnam (Stür et al. 2013), indicating that these issues can be overcome. Similarly, successful expansion of forage production and animal fattening was observed in Nong Het district, Xiangkhouang province of Laos after forages were introduced (Millar and Photakoun 2008). Both of these examples are upland areas that differ in many aspects from lowland systems. It is unclear if the successes in these mountainous areas can be transferred to the lowland rice ecosystems of Cambodia and Laos.

The awareness of existing limitations to livestock production, together with the mounting pressure to improve the productivity of grazing areas and the efficiency of labor, indicates that forages have the potential to be both useful and attractive to livestock producers in southern Laos and Cambodia. Furthermore, previous interventions in comparable sociocultural contexts have demonstrated the appropriateness and feasibility of integrating forages into existing farming systems as a means to intensify livestock production. However, they have also demonstrated that forages are neither universally embraced by, nor suitable for, all smallholder farmers. Poverty factors, including scarcities of land, labor, and cash, are frequently the reasons Lao farmers have provided to researchers for rejecting or dis-adopting livestock intensification practices (Millar and Photakoun 2008), despite forage growing being promoted as a remedy to these same scarcities (Peters et al. 2001; Stür et al. 2013). Forage interventions can only effectively contribute to livestock development for poor households if they meet their immediate needs and minimize exposure to risk (Millar and Photakoun 2008). To achieve this, farmers must be provided with options for growing forages that can cope with the constraints of their environment, use available or accessible germplasm, and use management methods that are likely to yield immediate and worthwhile benefits whilst reducing the risk of failure. These considerations are reviewed in subsequent sections.

\section{Land and water resources in rainfed lowland production systems of southern Laos and Cambodia}

Southern Laos and Cambodia are characterized by variable rainfall and low-fertility soils with sandy surface horizons of varying depths (Linquist and Sengxue 2001; Bell and Seng 2004). Understanding the constraints imposed by the available land and water resources and how they change seasonally and spatially across landscapes is essential for determining which species are best suited to integration into existing farming systems. This section first provides an overview of the climate and edaphic properties of rainfed lowland production systems of southern Laos and Cambodia, then identifies the common challenges and their implications for forage production.

\subsection{Climate}

Southern Laos and Cambodia both have a semi-arid tropical savannah climate with distinct wet and dry seasons. The wet season is associated with the southwest monsoon, bringing heavy winds, high humidity, and rainfall, and can be further split into the early wet season from April to July with the main wet season from July to October. The northeast monsoon occurs during the dry season from November to April, bringing cooler temperatures, lower humidity, less wind, and less rainfall (Ouerng et al. 2013; Thoeun 2015) (Fig. 3). This dry season is often referred to locally as drought, as there can be very little rainfall in the lowlands of either country between October and 
Fig. 3 Monthly mean minimum and maximum temperatures and mean monthly rainfall for Pakse, Champasak, The Lao PDR (source: Ministry of Water Resources and Meteorology), and Pochentong, Phnom Penh, Cambodia (source: Department of Meteorology and Hydrology, Ministry of Natural Resources and Environment)

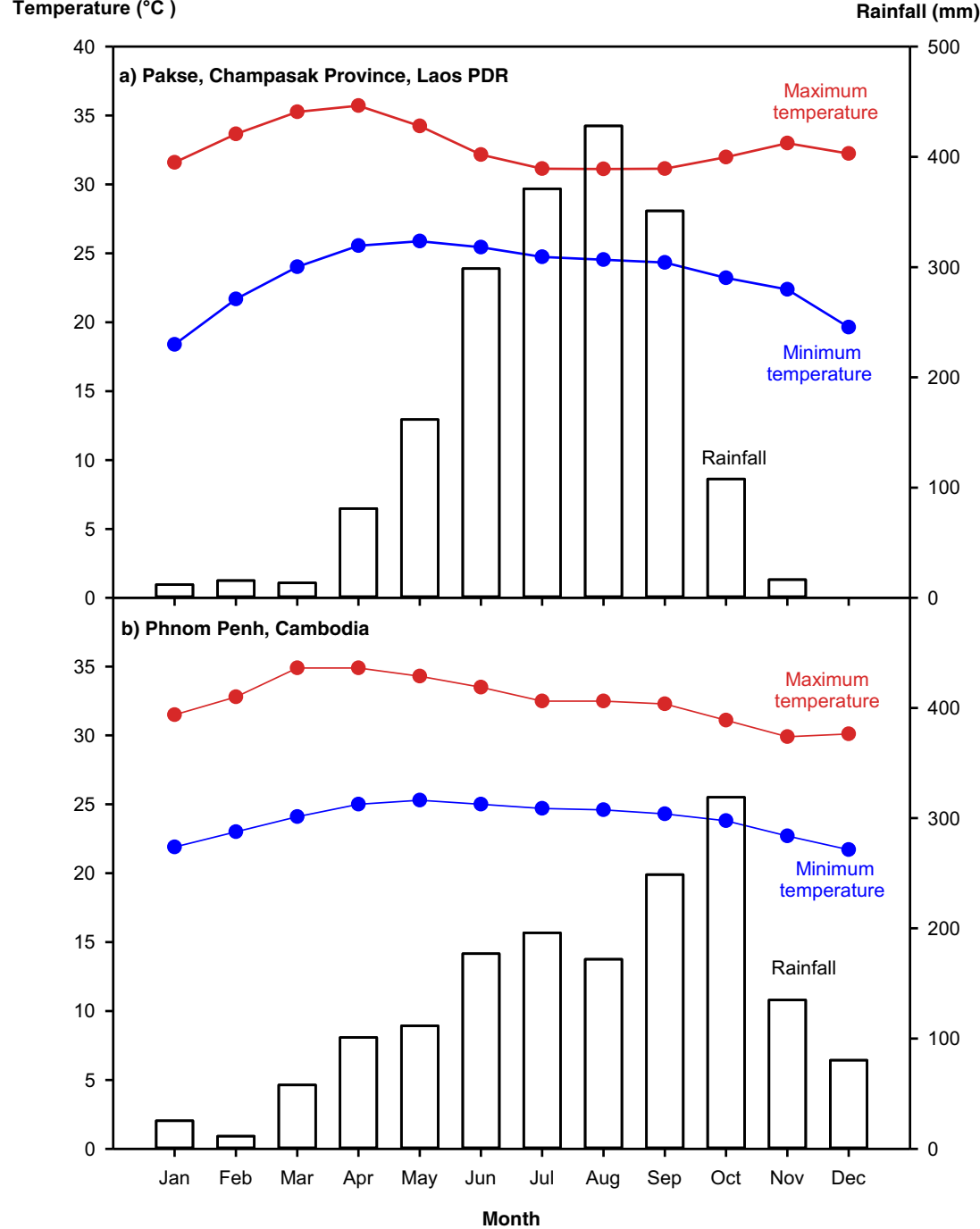

April (Fig. 4). The early wet season varies greatly across the region in reliability and intensity of rainfall between years (Fig. 4) and is characterized by a small peak in rainfall during April or May and a drier period in June (Nesbitt 1997; Fukai et al. 1998; Seng et al. 2009; Fukai and Ouk 2012). The main wet season rainfall has significant variation in intensity amongst years, although it is typically highest during August, September, and October (Fig. 4).

The maximum temperatures are reached during April-May, whereas the coolest months are October to January (Nesbitt 1997; Linquist and Sengxue 2001; Thoeun 2015). Across Cambodia, maximum temperatures can reach $45^{\circ} \mathrm{C}$, the mean maximum temperature is $38^{\circ} \mathrm{C}$, and the mean minimum temperature is $17^{\circ} \mathrm{C}$ (Nesbitt 1997; Thoeun 2015). Mean minimum and maximum temperatures are lower in northern Laos $\left(8^{\circ} \mathrm{C}\right.$ and $30{ }^{\circ} \mathrm{C}$ respectively) than southern Laos $\left(12{ }^{\circ} \mathrm{C}\right.$ and $\left.34{ }^{\circ} \mathrm{C}\right)$ (Linquist and Sengxue 2001; Lefroy et al. 2010).

The rainfall across Cambodia varies geographically, with lowland regions having a comparatively lower mean annual rainfall of 1250 to $1750 \mathrm{~mm}$, compared with $2500 \mathrm{~mm}$ in the northeast uplands and $4000 \mathrm{~mm}$ in the southwest coastal zone (Nesbitt 1997). Within the higher rainfall zones, mean monthly rainfall during the wet season reaches $600 \mathrm{~mm}$ and above, whilst the mean monthly rainfall does not exceed $400 \mathrm{~mm}$ in the drier zones (Thoeun 2015). Temporal variability also differs amongst provinces. Takeo Province in the southwest lowland rice region has lower minimum annual rainfall than Tbong Khmum Province in the southeast but higher maximum annual rainfall than Battambang Province in the northwest (Vance et al. 2004). The implications of these climatic differences for forage production systems have not been examined.

Across Laos, the annual rainfall is highly variable amongst regions, within provinces, and between years. The mean annual rainfall mostly ranges from $1200 \mathrm{~mm}$ to greater than $2400 \mathrm{~mm}$, but extremes occur as high as $3500 \mathrm{~mm}$ and as low as $1000 \mathrm{~mm}$ (Lefroy et al. 2010). There is a general increase in average annual rainfall from the west adjacent to the Mekong River to the mountain areas on the eastern margin of the country which 
Rainfall (mm)

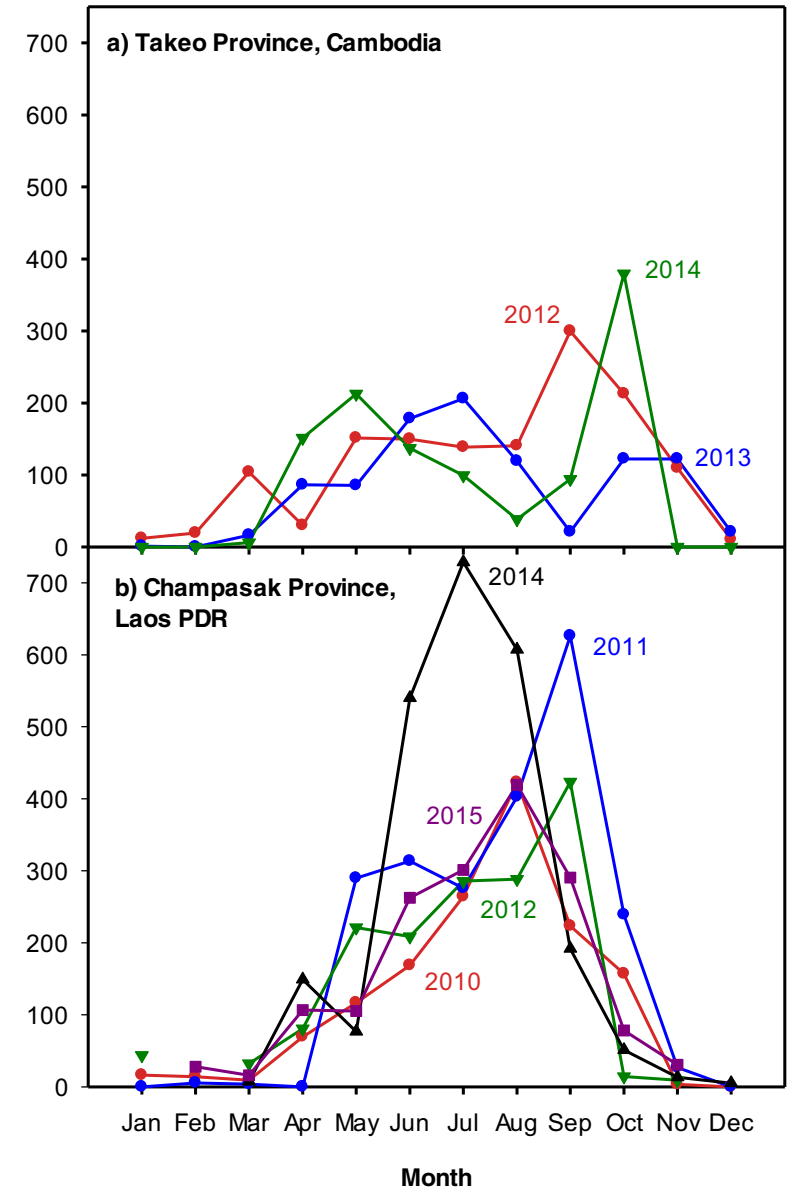

Fig. 4 Inter-annual variation in monthly rainfall at Takeo Province, Cambodia (Source: Ministry of Water Resources and Meteorology), and Champasak Province, The Lao PDR (Source: Department of Meteorology and Hydrology, Ministry of Natural Resources and Environment)

receives up to $2600 \mathrm{~mm}$ in both northern and southern Laos. In predominantly rice-growing lowland areas of southern Laos, mean annual rainfall is between 1500 and $2200 \mathrm{~mm}$ but is characterized by high temporal and spatial variability (Inthavong et al. 2004; Lefroy et al. 2010).

\subsection{Soil}

The rainfed lowland production systems of southern Laos and Cambodia are largely analogous with the main rainfed ricegrowing areas of the lower Mekong Basin, as they are largely underlain with similar siliceous sedimentary formations (Workman 1972; Carter and Bristow 2003). As a result, these regions are all substantially overlaid by soils characterized as coarse textured (Linquist and Sengxue 2001). The characteristics of the lowland rice soils and their limiting factors for wetland rice production have previously been mapped and described (SSLCC 1996; White et al. 1997a; Linquist and Sengxue 2001; Bell and Seng 2004; Fukai and Ouk 2012). Suitability for forages has not been mapped; however, compared with wetland rice, perennial forage systems on low-fertility soils have the added burden of multiple harvests, biomass removal, and subsequent plant regrowth (McRoberts et al. 2016).

In southern Laos, $68 \%$ of surface soils are characterized as sand, loamy sand, or sandy loam textured. These soils are most prevalent across areas of Savannakhét, Salavan, Champasak, and Attapeu Provinces, with elevations below $500 \mathrm{~m}$. Loamy sand-textured soils are also found in the uplands of Xékong Province (SSLCC 1996). In the rainfed lowland areas of Cambodia, $39 \%$ of soils have greater than $50 \%$ sand content with texture classes of silty loam and sandy loam (White et al. 1997a). A further $28 \%$ of soils are classified as silty clay to silty clay loam textures with $28-36 \%$ sand content, whilst the remaining $33 \%$ of soils are classified as silty clay soils with high clay contents of approximately $48 \%$ and low sand contents of 18\% (Seng et al. 2001; White et al. 1997a).

Low fertility has been reported in sand-dominant soils of both regions. In southern Laos, the majority of sand-dominant soils have a $\mathrm{pH}\left(\mathrm{H}_{2} \mathrm{O}\right)$ of less than 5.5 and organic matter content of less than 2\% (Linquist and Sengxue 2001), with low cation exchange capacity (CEC) also being typical (Lathvilayvong et al. 1996). Similarly, Cambodian soils in general have low CEC, organic carbon, and $\mathrm{pH}$ (White et al. 1997b; Bell and Seng 2004; Seng et al. 2005; Hin et al. 2010; Blair and Blair 2014). Nutrient omission studies across multiple sites in rainfed lowlands of southern Laos have demonstrated rice yield responses to applications of combined nitrogen, phosphorus, and potassium fertilizers, and responses to individually applied nitrogen, phosphorus, or potassium were respectively reported in approximately $90 \%, 70 \%$, and $30 \%$ of these sites (Linquist and Sengxue 2001). Whilst nutrient deficiency is prevalent across soils of southern Laos according to Linquist and Sengxue (2001), specific responses by soil types are not reported. Conversely, some differentiation in nutrient deficiencies for growing rice across the three Cambodian lowland soil classes was described in Bell and Seng (2004) and Seng et al. (2001). On the silty and sandy loams with greater than $50 \%$ sand content, nitrogen applied alone has not improved rice yields; however, greater responses have been reported with phosphorus applied alone or nitrogen and phosphorus applied together (Seng et al. 2001). These sandy soils also required additional potassium and sulfur to obtain comparable rice yields to other soil types. The silty clay and silty clay loam textured soils have low nutrient reserves but higher CEC (4 to $16 \mathrm{cmol}(+) \mathrm{kg}^{-1}$ ) and organic matter of $0.6 \%$ or above. The silty clay soils have the highest rice yield potential of the lowland soils, with higher CEC $\left(15 \mathrm{cmol}(+) \mathrm{kg}^{-1}\right)$ and greater organic carbon $(0.9 \%)$. These soils respond to nitrogen fertilizer applied alone but have no rice yield response to phosphorus applied alone due to higher Olsen phosphorus contents (4.6 mg kg${ }^{-1}$ ) (Seng et al. 2001). There has been no systematic study of micronutrient limitations on sands in southern Laos and Cambodia, but deficiencies of 
boron, copper, and molybdenum are common in northeast Thailand on sands derived from similar sedimentary rocks (Bell et al. 1990).

Nutrient availability and uptake of water in sandy soils are limited by low soil water storage (Seng et al. 2005). The rate of drying is such that rice on similar sandy soils from northeast Thailand expressed water stress within 1 week of rainfall ceasing, even in the presence of a less-permeable subsoil hardpan that would have slowed drainage (Sharma et al. 1995). The proportions of soils that are classified as drought prone in the rainfed lowland rice production regions were 33\% in Laos and 29\% in Cambodia (Wade et al. 1999; Bell and Seng 2004). Moreover, there has been a very limited study of crop and forage responses to fertilizer on the sand of southern Laos and Cambodia apart from those reviewed above for lowland rainfed rice.

\subsection{Implications of climate and soil resources for forage production}

Although typical lowland conditions on sandy soils are marginal for rice production, the variable cycle of flooding and drought greatly inhibits the options for alternative crops, including forages. Rainfall in the early wet season is critical for the establishment of crops and for minimizing the effects of drought on perennial forage systems, especially in circumstances where supplementary irrigation is not possible. The early wet season rainfall has the potential to produce valuable feed for livestock or a short duration crop before the main wet season. However, due to the variability in the commencement and intensity and reliability of rainfall in the early wet season, rainfed areas often remain in fallow during April to July, resulting in lost opportunities to capitalize on this rainfall when it occurs. During the main wet season, rainfall often floods lowland areas, creating hydrological conditions permissive of paddy rice but limiting potential forage choices to those which are adapted to waterlogging. The timing of the soil saturation or flooding in the lowlands is highly variable, and this uncertainty affects optimal timing of sowing and transplanting, which in turn alters the risk of later drought events coinciding with the grain-filling stage of rice growth (Inthavong et al. 2011). This uncertainty is less of a concern for biomass producing crops than grain crops, especially perennials that have already been established. Irrigation of forage plots can maintain survival and production during drought events and minimize the need for re-establishment of varieties that are less tolerant of drought (Ashley et al. 2018a).

Because the sand-textured soils have very limited water holding capacity, locations that experience waterlogging during the wet season often become extremely dry shortly after the cessation of rainfall. Consequently, rice soils are typically left fallow during the dry season because there is insufficient moisture available to grow common crop varieties, unless irrigation is available (Fukai and Ouk 2012). In rice fields, the frequent occurrence of plow pans at approximately 20$\mathrm{cm}$ depth exacerbates dryness in the root zone by preventing deep root penetration (Bruand et al. 2004). The ability of forage species to overcome this limitation is therefore an important criterion in their selection.

It is evident that lowland rainfed rice production systems of southern Laos and Cambodia are characterized by poor productivity, high risk, and high inefficiency of both nutrient and water use (Mainuddin and Kirby 2009; Tiemann et al. 2014a). Accordingly, there is a scope to substantially improve the productivity of these systems. The annual cycle of flooding and drought is an intrinsic property of farming systems on sandy soils of southern Laos and Cambodia, as are soil acidity and poor soil nutrition. The appropriateness of perennial forages as an option to sustainably intensify production on these soils depends on their compatibility with both the environmental and sociocultural properties of these systems (Descheemaeker et al. 2016).

\section{Available forage germplasm adapted to southern Laos and Cambodia}

The availability of suitably adapted forage germplasm limits the options immediately accessible to farmers who wish to intensify the production of animal feed. Although there always remains the potential to screen varieties and develop superior germplasm through participatory processes, much work has already been undertaken to identify and develop promising accessions for use in Southeast Asia. Breeding programs to improve the adaptation of tropical forages to stressors common in the tropics such as drought, flooding, and acidity have been underway since 1960 (Rao et al. 2015). The current selection of improved forage varieties under consideration for adoption in Cambodia and Laos has largely been shaped by two extensive programs of research: the Southeast Asian Forage Seed Project and the Forages for Smallholders Project. The Southeast Asian Forage Seed Project operated in Indonesia, Malaysia, Thailand, and the Philippines from 1992 to 1994, and identified six forage species and ten cultivars that were of suitably high quality relative to traditional feed resources and broadly adapted, particularly for acid soils (Stür et al. 1995): Andropogon gayanus "Kent" and "CIAT 621"; Brachiaria brizantha "Marandu"; Brachiaria decumbens "Basilisk"; Brachiaria humidicola "Tully," "CIAT 6369," "CIAT 16886," and "CIAT 6133"; Centrosema pubescens "Barinas"; and Stylosanthes guianensis "CIAT 184."

The Forages for Smallholders Project, which ran from 1995 to 2000, worked with these varieties and others that had been identified as promising at some sites or for certain purposes on-farm, to confirm their suitability to specific 
farming systems, to enhance adoption of these species in target areas, and to provide feedback on farmers' needs to researchers and extension services (Stür et al. 2002). The project expanded to include the Lao PDR (Millar and Photakoun 2008), south China, and Vietnam, evaluating more than 500 forage accessions that had shown potential in humid and subhumid environments in Australia, Latin America, sub-Saharan Africa, and Asia. Evaluations took place in nurseries located in high disease-incidence areas and acid, infertile soils, to eliminate those with poor growth, high pest or disease susceptibility, and an inability to propagate, and those with potential to become weeds in the region (Stür et al. 2002). More than 80 forage varieties were evaluated in this manner on sandy, acidic soils and in drought and flood-prone lowland areas of Laos specifically, during which time they were assigned a score on a five-point scale for their ability to maintain green leaves in the dry season (Phengsavanh and Phimphachanhvongsod 1998; Phimphachanhvongsod and Phengsavanh 1998). The selected accessions, combined with forage varieties already in use and previously identified by national research organizations, were successfully evaluated in researcher-managed regional evaluations and on-farm trials by farmers throughout Southeast Asia and southern China (Stür et al. 2000, 2002). The results from these evaluations are presented as a table of forage varieties, with adaptation to specific environmental conditions assigned a score on a three-point scale (Horne and Stür 1999; Stür et al. 2002). Accordingly, the findings of the Forages for Smallholders Project are a solid basis for forage development (Stür et al. 2002) and an ideal starting point for selecting varieties that are likely to be capable of persisting in lowland paddy ecosystems of Cambodia and Laos.

\subsection{Adapted varieties for southern Laos and Cambodia}

For this review, a matrix of suitably adapted cultivars for the lowland paddy ecosystems of Cambodia and Laos and their level of adaptation were generated by combining findings obtained from the Forages for Smallholders Project with information compiled within Tropical Forages: An Interactive Selection Tool (Cook et al. 2005). Tropical Forages: An Interactive Selection Tool is an expert system based on the experiences of over 50 forage specialists who have worked for many years in tropical and subtropical regions of Africa, subtropical USA, Central and South America, South and Southeast Asia, and Australia that contributed current information about cultivars, promising accessions, and the use of forages in a series of workshops held in Thailand, Australia, Colombia, Ethiopia, Germany, and Vietnam from 2001 to 2004 (Cook et al. 2005). The tool includes profiles for 180 species that assigns each a set of conditions and uses to which it is suited, including length of defined dry season ( $<6$ months; $>6$ months), average annual rainfall, soil drainage (well drained, occasional waterlogging, frequent waterlogging), length of inundation ( $<1$ week; $<1$ month; $>1$ month), soil fertility (high, medium, low), and soil $\mathrm{pH}(>7.5 ; 7 ; 6.5-5$; < $5)$. Each species is accompanied by a fact sheet that includes typical and maximum yields and other qualitative information about the species and cultivars. The selection tool does not systematically take into account the differing tolerances of cultivars within a species, unlike the previous evaluations conducted as part of the Forages for Smallholders Project (e.g., Phengsavanh and Phimphachanhvongsod 1998); however, these previous evaluations did not report responses to flooding in Laos.

The key constraints limiting the persistence of forages in the target environments are drought, flooding, and acidity. Hence, the matrix presented here assigns each variety a level of adaptation to each constraint, on a three-point scale. Adaptation to drought was assigned as a composite score for each species from three sources: the suitability for wet/dry tropics during the long dry season as reported in Stür et al. (2002), the ability to maintain green leaves in the dry season as reported in Phengsavanh and Phimphachanhvongsod (1998), and suitability for dry seasons greater than 6 months as reported by Cook et al. (2005). Adaptation to flooding was scored by taking the average of the three levels of adaptation to soil drainage and length of inundation according to Cook et al. (2005). Adaptation to soil acidity was assessed as a threepoint score of suitability to neutral soils, moderately acid soils, or extremely acid soils according to Stür et al. (2002), and the inverse of the lowest suitable soil $\mathrm{pH}$ range assigned in Cook et al. (2005). Tolerance to soil infertility was scored by combining the suitability to moderately fertile and infertile soils according to Stür et al. (2002), and the inverse of the lowest suitable fertility range assigned in Cook et al. (2005). Yield was scored based on the reported maximum annual DM yields per hectare in Cook et al. (2005), with $<10 \mathrm{t}$ scored as low, $10-20 \mathrm{t}$ as intermediate, and $>20 \mathrm{t} / \mathrm{ha}$ as high. Studies that evaluated broadly adapted forage varieties that were not available prior to 2005, and compared them to varieties scored through the previously described method, were also reviewed (Pizarro et al. 2013; Vendramini et al. 2014; Phengpet et al. 2016). The list of forages identified as having potential application in sand-textured soils of southern Laos and Cambodia is given in Tables 1 and 2 .

Of the varieties identified, only Brachiaria humidicola "Tully" and "Cayman", a three-way hybrid of Brachiaria brizantha, Brachiaria decumbens, and Brachiaria ruziziensis, have reportedly robust adaptations to drought, flooding, and soil acidity (Pizarro et al. 2013). Hybrid "Mulato 2" has comparable or greater drought persistence than "Cayman" and also greater persistence than both Brachiaria brizantha and Brachiaria decumbens cultivars, from which it is bred, but it is less able to cope with prolonged periods of flooding than "Cayman" (Phengpet et al. 2016). The yield potential of 
Table 1 Perennial grass varieties adapted to drought and/or waterlogging and soil acidity. Adapted from Stür et al. (2002) and Cook et al. (2005). Levels are indicated as high (green cells), moderate (yellow cells), and poor (red cells)

\begin{tabular}{|c|c|c|c|c|c|c|c|}
\hline Species & Adapted accession & \multicolumn{3}{|c|}{ Adaptation } & \multirow{2}{*}{$\begin{array}{c}\text { Forage } \\
\text { yield }\end{array}$} & \\
\hline Grasses & & Drought & Flooding & Acidity & Infertility & \\
\hline Andropogon gayanus & 'Kent' & & & & & \\
\hline Axonopus compressus & none & & & & & & Notes \\
\hline Brachiaria brizantha & 'Marandu' & & & & & & Lay cause photosensitization in small ruminants. \\
\hline Brachiaria decumbens & 'Basilisk' & & & & & & May cause photosensitization in small ruminants. \\
\hline Brachiaria humidicola & 'Tully' & & & & & & May cause photosensitization in small ruminants. Low palatability. Difficult to maintain. \\
\hline Brachiaria hybrid & 'Mulato 2' & & & & & & High forage yield/quality. Low seed yield. May cause photosensitization in small ruminants. \\
\hline Brachiaria hybrid & 'Cayman' & & & & & & High forage yield/quality. Low seed yield. May cause photosensitization in small ruminants. \\
\hline Brachiaria mutica & Para' & & & & & & \\
\hline Brachiaria ruziziensis & 'Ruzi' & & & & & & \\
\hline Panicum maximum & 'Tanzania' & & & & & & \\
\hline Paspalum atratum & 'Ubon' & & & & & & \\
\hline Paspalum plicatulum & Bryan' & & & & & & \\
\hline Pennisetum hybrid & 'King grass' & & & & & & Hery high seed yields \\
\hline Pennisetum purpureum & 'Napier' & & & & & & High yields under good conditions. Can tolerate poor conditions but is not productive. Prickly \\
\hline Setaria sphacelata & 'Lampung' & & & & & & High oxalate levels can cause animal disease, especially amongst monogastric animals. \\
\hline Urochloa mosambicensis & 'Nixon' & & & & & & \\
\hline
\end{tabular}

"Mulato 2" is, however, higher than that of other Brachiaria species and hybrids. The third parent species, Brachiaria ruziziensis, is reported not to share the broad adaptation of the other two Brachiaria parent species (Horne and Stür 1999).

Outside the Brachiaria genus, Andropogon gayanus "Kent" and the legume Stylosanthes guianensis "CIAT 184" are reported to have strong performance under protracted dry and acid-infertile soil conditions, whilst also having some moderate tolerance of flooding (Cook et al. 2005; Phengsavanh and Phimphachanhvongsod 1998). Tree legumes Albizia lebbeck, Gliricidia sepium, and Sesbania grandiflora, and grasses Panicum maximum "TD 58," Setaria sphacelata "Lampung," Urochloa mozambiquensis "Nixon," Pennisetum purpureum "Napier," and Pennisetum hybrid "King grass" have generally moderate tolerances to the constraints identified previously (Stür et al. 2002; Cook et al. 2005; Gabunada Jr et al. 2007; Phengsavanh and Phimphachanhvongsod 2007). "Tully," Brachiaria mutica, and Paspalum atratum "Terenos" have reported strong tolerances for both soil acidity and flooding, but poor persistence during long dry seasons without irrigation (Tuhulele et al. 2007; Cook et al. 2005; Nakamanee and Phaikaew 1998). Tree legume Erythrina poeppigiana shares similar tolerances to "Tully" and "Terenos" (Cook et al. 2005).

\subsection{Other traits affecting compatibility with farming systems}

Traits affecting the acceptance and ease of managing tropical forages by farmers are often poorly documented in scientific literature and difficult to identify ahead of evaluation but are often critical factors for adoption by farmers (Tuhulele et al. 1998; Stür et al. 2002). For example, Brachiaria ruziziensis is commonly grown in areas outside its expected adaptive range, such as northeast Thailand, even when higher forage-yielding varieties for the same environment such as Brachiaria decumbens were available (Stür et al. 1996). The reason for this appears related to both the high seed yield and the

Table 2 Perennial herbaceous legume varieties adapted to drought and/or waterlogging and soil acidity. Adapted from Stür et al. (2002) and Cook et al. (2005). Levels are indicated as high (green cells), moderate (yellow cells), and poor (red cells)

\begin{tabular}{|c|c|c|c|c|c|c|c|}
\hline \multirow{2}{*}{$\begin{array}{c}\text { Species } \\
\text { Legumes }\end{array}$} & \multirow[t]{2}{*}{ Adapted accession } & \multicolumn{4}{|c|}{ Adaptation } & \multirow{2}{*}{$\begin{array}{c}\text { Forage } \\
\text { yield }\end{array}$} & \multirow{2}{*}{ Notes } \\
\hline & & Drought & Flooding & Acidity & Infertility & & \\
\hline Albizia lebbeck & None & & & & & & \\
\hline Arachis glabrata & None & & & & & & Slow and costly establishment. difficult to cut \\
\hline Arachis pintoi & Amarilo' & & & & & & Slow and costly establishment. difficult to cut \\
\hline Centrosema brasilianum & Ooloo' & & & & & & Difficult to cut \\
\hline Centrosema macrocarpum & 'Ucayali' & & & & & & Difficult to cut \\
\hline Centrosema pubescens & 'Barinas' & & & & & & Difficult to cut \\
\hline Chamaechrista rotundifolia & 'Wynn' & & & & & & Low palatability \\
\hline Cratylia argentea & Veranera' & & & & & & \\
\hline Desmodium cinereum & Las Delicas' & & & & & & \\
\hline Erythrina poeppigiana & None & & & & & & Tree, slow establishment. Seed, root and bark toxicity \\
\hline Gliciridia sepium & 'Retalhuleu' & & & & & & Tree, slow establishment. Seed, root and bark toxicity \\
\hline Leucaena leucocephala & 'Tarramba' & & & & & & Tree, slow establishment. \\
\hline Lotononis bainesii & Miles' & & & & & & Slow and difficult establishment \\
\hline Sesbania grandiflora & None & & & & & & Tree \\
\hline Stylosanthes capitata & Campo Grande' & & & & & & \\
\hline Stylosanthes guianensis & 'CIAT 184' & & & & & & Low persistence under intense defoliation. \\
\hline Stylosanthes fruticosa & None & & & & & & Low persistence under intense defoliation. \\
\hline Stylosanthes hamata & 'Verano' & & & & & & \\
\hline Stylosanthes macrocephala & Campo Grande & & & & & & Difficult to cut \\
\hline Stylosanthes scabra & Siran' & & & & & & Low palatability \\
\hline
\end{tabular}


convenient timing of seed production relative to the annual rainfall patterns (Hare et al. 2005), which have also made the variety a popular choice for seed distribution by local institutions, who benefit from producing the seed. Thus, ease of propagation may also be an important trait for the selection of forage species by farmers. Similarly, previous research and extension with traditional farmers in Southeast Asia have found that farmers that were constrained by feed and labor availability had a strong preference for grasses over legumes when selecting varieties for use on their farms because they prioritized quantity of forage and palatability to cattle (Gabunada Jr et al. 2007; Stür et al. 2007; Tuhulele et al. 2007; Ba et al. 2014), which is generally higher in grasses compared with legumes. There may be a risk of farmers overlooking higher quality varieties due to their perception or lack of perception of quality.

The following 14 traits were identified by smallholders as being desirable in their evaluation of forage varieties as part of the Forages for Smallholders Project (Stür et al. 2002):

1. Planting material that is easy to collect

2. Easily propagated

3. Herbage that is easy to cut

4. Not itchy when cutting

5. Cut material that is easy to collect and transport

6. High forage yield

7. Fast regrowth after harvesting

8. Good survival when harvested frequently

9. Liked by animals

10. Potential to save labor

11. Eaten quickly and satisfying for animals

12. Good growth throughout the year

13. Not competitive with adjacent crops

14. Multiple benefits (e.g., erosion control, ground cover, ornamental value).

In addition, the selection of cultivars should consider effects on animal health. Some Brachiaria species have been reported to induce lethal photosensitization in sheep, goats, and small cattle/calves when fed in higher amounts (Horne and Stür 1999). High oxalate levels in Setaria sphacelata also limit its value as a source of forage, especially as the major component of a diet (Cook et al. 2005). Some information about the management traits of individual species has been incorporated in Table 1.

\subsection{Availability of adapted varieties}

The performance and broad adaptation of Brachiaria hybrids "Mulato 2" and "Cayman" make these varieties ideal candidates for integration into existing systems. However, the uptake of both hybrids is limited by the availability and accessibility of seed in the target regions. There is a high prevalence of sterility reported for hybrid Brachiaria pollen, which leads to a failure of $90 \%$ of spikelets to produce viable seed (Hare 2014). Seed production by households is therefore challenging (Cook et al. 2005), although commercial Mulato seed production in Northern Laos has been established based on a strong and mutually beneficial business model (Hare 2014). Smallholder produced "Mulato 2" seed is commercially available from Ubon Ratchathani University in Thailand, as are locally produced Panicum maximum, Paspalum atratum, and Stylosanthes guianensis seed (Hare 2014), all of which are broadly adapted and potentially viable for use in southern Laos and Cambodia (Table 1). The successful model of seed system development is described in Hare (2014). Distribution of "Cayman" however has ceased due to poor seed yields from the hybrid crop in village-based production systems in Thailand. Given these challenges in "Cayman" seed production, there may be merit in future research revisiting easily produced Brachiaria brizantha and Brachiaria decumbens for adoption in southern Laos and Cambodia. Of the remaining varieties identified in Table 1, Andropogon gayanus presents a notably broad adaptation corresponding favorably with the conditions of southern Laos, as demonstrated during promising but limited evaluations by the Forage for Smallholders Project (Phengsavanh and Phimphachanhvongsod 1998). Commercial seed availability of cultivar "Kent" ended in Australia after Andropogon gayanus was declared a weed of national significance (Cook et al. 2005). Some "Kent" remains in northern Laos in former Forages for Smallholders Project sites which may be a resource to resume evaluating this variety and to introduce it into smallholder systems if found to be productive and desirable to farmers; however, the risk of it becoming an environmental weed should be considered before any reintroduction. "Ruzi," "Tully," "Napier," and "King Grass" are available throughout the region. Other varieties found to be suitable would require the development of local seed infrastructure.

\section{Developing compatible forage options for southern Laos and Cambodia}

The best-adapted varieties for producing feed on acidic, sandtextured soils in southern Laos and Cambodia, which are also immediately accessible to farmers, are limited to Brachiaria brizantha "Marandu," Brachiaria decumbens "Basilisk," Brachiaria humidicola "Tully," Brachiaria mutica, Brachiaria hybrid "Mulato 2," Stylosanthes guianensis "CIAT 184," Panicum maximum "TD 58," and Paspalum atratum "Terenos" and "Ubon." Of these varieties, all but Brachiaria mutica have a good record of successful adoption and use by farmers in Laos (Phengsavanh and Phimphachanhvongsod 2007), whilst all have been introduced to Cambodia, with excellent performance (Young 
et al. 2014; Bush et al. 2014b). Although the grass species listed produce a quantity of forage that is generally higher than the legumes (Gabunada Jr et al. 2007; Stür et al. 2007; Tuhulele et al. 2007), on acidic, water-limited soils "CIAT 184 " has the potential to exceed both the biomass and nutritive value of some adapted grasses when managed carefully (Cook et al. 2005), making it a viable candidate for inclusion in farming systems of southern Laos and Cambodia despite the limitations associated with some legumes (Sumberg 2002).

No variety performs well when nutrient is limited; however, some varieties such as Brachiaria brizantha, Brachiaria decumbens, and Stylosanthes guianensis have much lower internal requirements for phosphorus, potassium, and calcium than other varieties such as "King Grass" and "Ruzi" (Corrêa and Haag 1993; Rao et al. 1996; Pinkerton et al. 1997). Similarly, no varieties are productive when water is limited. Given the length of the dry seasons of southern Laos and Cambodia, even the varieties identified as possessing greater ability to maintain green leaves in the dry season will likely experience extended periods with little to no growth, unless irrigation is available. Of those identified that persist further into long dry seasons, few can cope with periods of flooding typical of the wet season, with the possible exception of "Cayman." Accordingly, the selection of the best-adapted varieties for farmers in southern Laos and Cambodia must also be complemented with management strategies that minimize exposure to stressors.

\subsection{Management of drought}

Of the main stressors identified as being most limiting to production in ecosystems with sand-textured soils in southern Laos and Cambodia, drought is the most challenging to overcome. Dry season irrigation has been an essential input for livelihood transformations arising from forage adaption in southeast Asia (Ba et al. 2013; Stür et al. 2013), including Cambodia (Ashley et al. 2018b). In these systems, forages are typically grown close to the homestead (Ba et al. 2013; Young et al. 2014), where collected rainwater is traditionally available from ponds and used for the irrigation of vegetable gardens. For farmers who can irrigate forages, the risks of adoption are much lower and the benefits to animal production during the dry season are likely to be much greater.

Management may also be necessary to allow forages with drought resistance to express their adaptations. Drought resistance is often a result of deep rooting traits that allow plants to access water that is stored deeper in the soil profile, such as in subsoils with greater clay content. This drought avoidance characteristic is especially critical to survival and growth on the soils typical of the region because the sand-dominant horizons, which may exceed $100-\mathrm{cm}$ depth, rapidly dry in the absence of sustained rainfall (Bell and Seng 2004). However, there are challenges intrinsic to sandy soils in southern Laos and Cambodia that can limit deep root growth and prevent drought avoidance. Significant proportions of these sandy soils are strongly acidic (Seng et al. 2007; Fukai and Ouk 2012), having the potential to greatly inhibit root development and exploration by sensitive cultivars, thereby preventing water extraction from the deeper horizons. Furthermore, the prevalent plow pans are a significant impediment to root penetration into deeper soil layers, preventing them from accessing subsoil water storage for dry season growth and survival. Deep tillage to disrupt the hardpan has been demonstrated to improve water use efficiency and productivity by dry season crops sown in sandy soils of Laos, without yield penalties to subsequent rice crops (Vial et al. 2013). Straw mulching has also been shown to improve dry season mungbean yield in Cambodian rice fields with strongly compacted soils (Bunna et al. 2011). Conversely, it has been reported in northeast Thailand that deep tillage of sands is often prohibitively expensive for smallholders and largely ineffective at reducing compaction due to the rapid collapse of the structurally unstable soils (Lesturgez et al. 2004). An economic assessment of hardpan disruption based on experimental data with irrigated dry season maize estimated that hardpan disruption gave gross benefits 2.7-9.8 times the costs of disruption (Vial et al. 2013), which indicates that it could be a worthwhile investment for smallholder forage producers with access to the labor and resources to implement it.

An alternative to mechanically disrupting the hardpan is the use of varieties with roots capable of penetrating the compacted layer to access subsoil moisture without the need for tillage. In northeast Thailand, Stylosanthes hamata roots have been shown to grow through and proliferate gradually over 24 months below a $20-40 \mathrm{~cm}$ layer with high penetration resistance on deep sands (Lesturgez et al. 2004). It is likely that root penetration capability varies amongst species although this has not been compared across tropical grasses.

The selection of varieties that can avoid or resist drought is critical to the establishment of perennial forages in rainfed areas of Cambodia and Laos, especially when deep tilling of hardpans is not viable. However, experience from other countries in the region indicates that access to irrigation can greatly increase dry season productivity.

\subsection{Management of soil acidity}

Soil acidity can be managed in surface layers not only through inputs of lime but also through the application of compounds such as humates, silicates, or organic matter in the form of manure and crop residues (Wong and Swift 2003). The application of lime and $\mathrm{P}$ to low $\mathrm{pH}$ clayey and sandy soils in Cambodia under unsaturated conditions has reduced soluble aluminum and increased plant phosphorus uptake (Seng et al. 2006). Similarly, the application of lime to low pH clay and sandy loam soils of Laos increased $\mathrm{pH}$ and the concentrations of phosphorus, 
calcium, and magnesium, whilst decreasing concentrations of manganese and aluminum (Phengsouvana et al. 2009). Accordingly, plants with a preference for less acidic soils may persist in the target soils after liming, and their nutrient use efficiency can be improved, albeit with greater input costs that may render this strategy unaffordable to smallholders in the region. Furthermore, acid-susceptible varieties may still struggle to develop roots at depth in deep acid sands because surface lime applications have a limited effect on subsoil acidity, thereby diminishing their capability to avoid drought stress.

In addition to the inherent acidity of the sands in southern Laos and Cambodia, high productivity forage systems are generally strongly acidifying due to high rates of ammonium-N fertilizer application or symbiotic nitrogen fixation and the removal of large amounts of biomass (Noble et al. 2000). The sands of northeast Thailand have limited $\mathrm{pH}$-buffering capacity, and $\mathrm{pH}$ decline can occur rapidly when the cropping or forage production system is strongly acidifying (Lesturgez et al. 2006). Hence, liming may eventually become critical to maintain $\mathrm{pH}$ and prevent soil degradation in forage plots caused by acidification.

\subsection{Management of soil nutrition}

Poor soil nutrition can only be addressed by the addition of nutrients that are lacking in the quantities required for plant growth, in the form of fertilizer, manure, or other soil amendments. The nutrient requirements for achieving worthwhile forage yields on sandy soils are likely to be considerably higher than those of rice. Pheav et al. $(2003,2005)$ found that $27 \mathrm{~kg}$ of phosphorus per hectare was required annually to maintain a positive phosphorus balance for continuous rice crops on sandy duplex soil in Cambodia. By contrast, Nakamanee et al. (2008) estimated that $83 \mathrm{~kg}$ of phosphorus per hectare was removed annually as cut forage from established Panicum maximum and Brachiaria ruziziensis fields belonging to commercialized smallholder forage systems in northeast Thailand, in addition to $920 \mathrm{~kg}$ of nitrogen and $694 \mathrm{~kg}$ of potassium. Chemical fertilizer and manure inputs in the examined systems contributed nitrogen and phosphorus in greater quantities than they were removed as forage, but not potassium or sulfur (Nakamanee et al. 2008). In lowfertility sandy soils of South-Central Vietnam, additions of urea and manure improved yields of Brachiaria cv. Mualto II in sandy soils (McRoberts et al. 2016). However, partial nutrient balances were negative for $\mathrm{N}, \mathrm{P}$, and $\mathrm{K}$ (McRoberts et al. 2018).

Although chemical fertilizers are recommended for crop production on sandy soils in Cambodia, effective yield responses from trials are often only reported with application rates that are beyond what is accessible by typical smallholder farmers (Blair and Blair 2014). Fertilizer use efficiency is often poor on sands because their low reactive surface area and high permeability allow nutrients to rapidly leach once they are applied (Sitthaphanit et al. 2009), especially when rainfall is intense. Accordingly, nutrients are unlikely to be carried over to subsequent crops, resulting in wastage if fertilizer application exceeds crop demand (Bell et al. 2001). A survey of established forage growers from two villages in differing physiographic regions of Cambodia found that the households in a region characterized by sandy duplex soil typically had higher nutrient inputs over smaller areas on average, compared with farmers in an upland region characterized by clayey topsoil (Ashley et al. 2018a), which may be an adaptation to the limitations of the soil.

Loss of fertilizers from leaching may be addressed by splitting fertilizer applications (Sitthaphanit et al. 2009). Splitting applications also allow for the strategic timing of nutrient delivery, such as following grazing or defoliation, thereby matching fertilizer applications to crop demand to improve efficiency (Bell et al. 2001). Furthermore, when applications are split, the risk of losing nutrients to intense rainfall and flooding soon after the application is reduced. Accordingly, it is necessary to understand nutrient deficiencies in the target systems and implement site-specific nutrient management (Bell et al. 2008) to ensure profitable and sustainable use of fertilizer. Leaching itself may also be reduced by combining fertilizer with organic soil amendments. Combining fertilizer additions with organic soil amendments has been shown to improve the efficiency of fertilizer uptake on sand-dominant soils of northeast Thailand (Ragland and Boonpuckdee 1987) and South-Central Vietnam (Hoang et al. 2015b), possibly because it reduces the rate of nutrient leaching, as well as improving the moisture holding capacity of soils.

Inefficient use of typical fertilizer inputs also occurs if one or more limiting nutrient deficiencies remain or occur in the soil after application, such as sulfur or micronutrients (Bell et al. 1990; Bell and Dell 2008; Hoang et al. 2015a). Sulfur and potassium deficiencies are commonly undiagnosed on sands while nitrogen and phosphorus may be oversupplied (e.g., Hoang et al. 2015a). In addition, micronutrient deficiencies are common (e.g., Bell et al. 1990; Hoang et al. 2015a). Nitrogen fixation by legume forages may be limited by molybdenum deficiency (e.g., Bell et al. 1990). There have been no studies in Cambodia or Laos to determine the sufficiency of cobalt (Bell and Dell 2008) or nickel for symbiotic nitrogen fixation in legume forages (Freitas et al. 2018).

\subsection{Management of flooding}

Local surface hydrology can vary on-farm to such an extent that flooding occurs in specific fields due to local features such as roads, bunds, drains, and dams. Furthermore, a study of the effect of toposequence on soil properties and hydrology in rainfed lowlands in sandy terrain in northeast Thailand found 
that sites in upper positions on toposequences were consistently drier than those at lower positions, with standing water at the surface being shallower, groundwater being deeper, and the number of cumulative days without ponded surface water being fewer during the rice-growing season (Boling et al. 2008). This indicates that upper fields are more appropriate for varieties that are susceptible to flooding. Toposequences are therefore an important consideration at the farm and village scale for determining fields where flood-susceptible varieties may persist on sands across southern Laos and Cambodia. Low-lying flood-prone areas of the farm may conversely be exploited with varieties that prefer poorly drained soils.

\subsection{Forage niches}

According to the socio-ecological niche concept developed by Ojiem et al. (2006), variations in local ecological factors, including the prevalence of drought, soil infertility, and flooding, define which technologies are compatible with farming systems. This has been demonstrated in Sen Ouk and surrounding villages of Takeo province of Cambodia, where two distinct forage niches have emerged during farmer participation in a 3-year research project (Ashley et al. 2018a). The first and most common forage niche is characterized by lowlying ecosystems surrounding the elevated foundation of the homestead, usually with access to irrigation, which are typically used to grow Paspalum atratum "Terenos" and/or Brachiaria mutica. The preference of these two species for poorly drained soils ensures high productivity during the wet season, at which time low-lying areas are regularly flooded. Although Paspalum atratum "Terenos" can survive drought conditions, it is unproductive, therefore irrigation is usually necessary to maintain survival and productivity in both it and the highly drought-susceptible Brachiaria mutica during the dry season. The second niche ecosystem is characterized by raised areas including front and back yards, hills, sloping land, upper terraces, bunds, and building foundations, which is often used to grow drought-tolerant, flooding-susceptible varieties Brachiaria hybrid "Mulato 2" and Panicum maximum "Tanzania" and "Mombasa." In these environments, the forages are at a reduced risk of prolonged flooding; however, deep-rooting characteristics allow the forages to access subsoil water and minimize drought exposure during the dry season, potentially delaying or preventing the onset of yellowing leaves and loss of productivity. It is not uncommon for both ecosystems to exist within the same farm, and current forage users have a perception of whether a variety is an "upland" or "lowland" variety, which corresponds to the niches described above.

Both niches described in Sen Ouk and surrounds are intrinsic to traditional lowland rice systems in Cambodia and Laos and it is common for both ecosystems to exist within the same farm. Participatory approaches are especially suited for identifying if, and where, these niches and others exist, and if exploiting them can meet the needs of farmers. Should forages be found compatible, a stepwise approach to engaging smallholder farmers in forage production has been consistently employed in previous interventions, including in southern Laos, with varied success (Millar and Connell 2010; Tiemann et al. 2014b). This process involves researchers and extension workers introducing farmers to forage growing and assisting them to establish forages on a small scale, but large enough to accrue some labor and animal performance benefits. Previous research indicates that 800 to $1000 \mathrm{~m}^{2}$ of improved grass per animal is sufficient (Stür et al. 2007), although high-performing areas of $500 \mathrm{~m}^{2}$ have been reported to provide sufficient benefit for farmers to invest in the expansion of their forage areas in Vietnam (Ba et al. 2013).

\subsection{Additional requirements for sustainably intensifying animal production with forages}

Transitioning to forage production creates new requirements and opportunities for animal management. Controlling the access of animals to new forage plots is essential. Access may be managed by village regulations, particularly where tethered grazing is practiced for the entire year, although the installation of a physical barrier is likely to be a more common and reliable solution, particularly where the presence of green feed in the dry season is highly conspicuous. The need to fence relatively large areas may present a significant challenge to the establishment of forages, with potential constraints including village regulations, labor availability, and fencing materials (Tiemann et al. 2014a). The potential for tree legume species to function as barriers whilst still producing highquality feed (Stür et al. 2002) may represent an opportunity to mitigate this cost. It is expected that once forages are adopted and adopters are confident in the benefits obtained, they will be better placed to improve other aspects of management (Tiemann et al. 2014b) and will take advantage of opportunities to intensify cattle production (Millar and Connell 2010; Bush et al. 2014b; Tiemann et al. 2014b).

Enhancements to confined feeding systems made possible by cut-and-carry feeding regimes permit greater management of livestock health and breeding (Tiemann et al. 2014b). The technical knowledge required for the transition from traditional management of livestock to more sophisticated animal production is small (Tiemann et al. 2014a). However, barriers exist, particularly with regard to the poor understanding of animal husbandry and cultural views relating to the role of animals in production systems (Tiemann et al. 2014b; Bush et al. 2014b; Lefroy et al. 2010). Support is therefore necessary for farmers to develop profitable animal production systems and to fully enter livestock markets. A successful program that supports knowledge, attitudes, and practices of livestock farmers is described by Young et al. (2014): it prioritized vaccinations against transboundary animal diseases, forage 
development, and husbandry training. The outcome was a significant increase in incomes, including a doubling of income for more than half of the assessed farmers (Young et al. 2014).

\section{Conclusion}

Sustainable intensification of livestock production involving the integration of perennial grasses and legumes is an opportunity for improvement of livelihoods in rainfed lowland rice farming systems, such as those of southern Laos and Cambodia. A range of broadly adapted perennial tropical grasses and herbaceous legumes have been identified, many of which have been evaluated in a diverse set of challenging conditions in Southeast Asia. Broadly adapted species currently accessible to farmers include Brachiaria sp. hybrid "Mulato II," Panicum maximum, Paspalum atratum, and Stylosanthes guianensis. However, none of these varieties are well adapted to both flooding and drought, which are major constraints on most lowland ecosystems of southern Laos and Cambodia. As observed in Cambodia, variations in surface hydrology typical at the farm scale, particularly between upper and lower sandy terraces, allow farmers to exploit differentiated environments suitable for differing forage varieties. Brachiaria sp. hybrid "Mulato II," Panicum maximum, and Stylosanthes guianensis are recommended for drought-prone, acidic sands that are at low risk of prolonged submergence. Conversely, ecosystems lower in the toposequences that are prone to temporary inundation in the early wet season and hold residual water later in the year may be used to produce varieties tolerant of flooding and with higher water demands such as Paspalum, but these varieties may require supplementary irrigation in the dry season. The transition to perennial forage growing can be achieved by farmers with the available forage species and it is possible for farmers to rapidly accumulate benefits in terms of labor saving; however, low nutrient status of soil, continual removal of nutrients in harvested forage, and the risk of acidification must be carefully managed. Furthermore, support to manage increased animal production and to access markets is necessary for farmers to intensify their animal production systems to gain the most advantage from forage adoption.

Acknowledgments The Australian Centre for International Agricultural Research provided funding for this research through project SMCN.2012.075. We thank Dr. Werner Stür for providing helpful feedback on this review. GIS support was provided by Dr. Xueling Li. Germplasm used in this project was provided by the Australian Pastures Genebank.

\section{Compliance with ethical standards}

Conflict of interest The authors declare that they have no conflict of interest.

\section{References}

Ashley K, Wilson S, Young JR, Chan HP, Vitou S, Suon S, Windsor PA, Bush RD (2018a) Drivers, challenges and opportunities of forage technology adoption by smallholder cattle households in Cambodia. Trop Anim Health Prod 50:63-73. https://doi.org/10.1007/s11250017-1400-y

Ashley K, Young JR, Kea P, Suon S, Windsor PA, Bush RD (2018b) Socioeconomic impact of forage-technology adoption by smallholder cattle farmers in Cambodia. Anim Prod Sci 58:393-402. https:// doi.org/10.1071/AN16164

Ba NX, Lane PA, Parsons D, Van NH, Khanh HLP, Corfield JP, Tuan DT (2013) Forages improve livelihoods of smallholder farmers with beef cattle in South Central Coastal Vietnam. Trop Grassl 1(2): 225-229. https://doi.org/10.17138/tgft(1)225-229

Ba NX, Van NH, Scandrett J, Vy LV, Tung HV, Nghi NT, Tuan DT, Lane P, Parsons D (2014) Improved forage varieties for smallholder cattle farmers in south central coastal Vietnam. Livest Res Rural Dev 26(9): 158

Bell RW, Dell B (2008) Micronutrients in sustainable food, feed, fibre and bioenergy production. IFA, Paris

Bell RW, Seng V (2004) Rainfed lowland rice-growing soils of Cambodia, Laos and Northeast Thailand. In: Seng V, Craswell E, Fukai S, Fischer K (eds) Water in Agriculture. Phnom Penh, Cambodia, pp 161-173

Bell RW, Rerkasem B, Keerati-Kasikorn P, Phetchawee S, Hiranburana N, Ratanarat S, Pongsakul P, Loneragan JF (1990) Mineral nutrition of food legumes in Thailand with particular reference to micronutrients. ACIAR Technical Report 19, pp 52

Bell RW, Ros C, Seng V (2001) Improving the efficiency and sustainability of fertilizer use in drought-and submergence-prone rainfed lowlands in South-East Asia. In: Fukai S, Basnayake J (eds) Increased lowland rice production in the Mekong region. ACIAR Proceedings 101. ACIAR, Canberra, pp 155-169

Bell R, Seng V, Schoknech N, White F 2008. Assessing land suitability for crop diversification in Cambodia and Australia. ACIAR Project Final Report

Bell RW, Hoang MT, Summers R, Parsons D, McKay A (2015) Opportunities and priorities for further investment in improving the productivity and sustainability of crop and livestock systems on sands in south-central coastal Vietnam. In: Mann S, Webb MC, Bell RW (eds) Sustainable and profitable crop and livestock systems in south-central coastal Vietnam. ACIAR Proceedings No. 143. ACIAR, Canberra, pp 228-240

Blair G, Blair N (2014) Nutrient status of Cambodian soils, rationalisation of fertiliser recommendations and the challenges ahead for Cambodian soil science. Curr Agric Res 2(1):05-13. https://doi. org/10.12944/CARJ.2.1.02

Boling AA, Tuong TP, Suganda H, Konboon Y, Harnpichitvitaya D, Bouman BAM, Franco DT (2008) The effect of toposequence position on soil properties, hydrology, and yield of rainfed lowland rice in Southeast Asia. Field Crop Res 106(1):22-33. https://doi.org/10. 1016/j.fcr.2007.10.013

Bruand A, Hartmann C, Ratana-Anupap S, Sindhusen P, Poss R, Hardy M (2004) Composition, fabric and porosity of an Arenic Haplustalf in Northeast Thailand: relation to penetration resistance. Soil Sci Soc Am J 68(1):185-193. https://doi.org/10.2136/sssaj2004.1850

Bunna S, Sinath P, Makara O, Mitchell J, Fukai S (2011) Effects of straw mulch on mungbean yield in rice fields with strongly compacted soils. Field Crop Res 124(3):295-301. https://doi.org/10.1016/j.fcr. 2011.06.015

Bush RD, Page B, Macdonald T, Young JR, Nampanya S, Suon S, Khounsy S, Henry LA, Thomson PC, Windsor PA (2014a) Target feeding for improved smallholder beef production in the Mekong 
region: lessons from Cambodia and Lao PDR. Anim Prod Sci 54(9): 1219-1223. https://doi.org/10.1071/AN14133

Bush RD, Young JR, Suon S, Ngim MS, Windsor PA (2014b) Forage growing as an incentive to improve smallholder beef production in Cambodia. Anim Prod Sci 54(10):1620-1624. https://doi.org/10. 1071/AN14136

Carter A, Bristow CS (2003) Linking hinterland evolution and continental basin sedimentation by using detrital zircon thermochronology: a study of the Khorat Plateau Basin, eastern Thailand. Basin Res 15: 271-285. https://doi.org/10.1046/j.1365-2117.2003.00201.x

Cook BG, Pengelly BC, Brown SD, Donnelly JL, Eagles DA, Franco MA, Hanson J, Mullen BF, Partridge IJ, Peters M, Schultze-Kraft R (2005) Tropical forages: an interactive selection tool. CD-ROM, CSIRO, DPI\&F(Qld), CIAT and ILRI, Brisbane

Corrêa L, Haag H (1993) Critical levels of phosphorus for the establishment of pasture grasses on a Red Yellow Latosol. I: greenhouse test. Sci Agric 50(1):99-108. https://doi.org/10.1590/S010390161993000100014

Dawe D (2005) Increasing water productivity in rice-based systems in Asia - past trends, current problems, and future prospects. Plant Prod Sci 8(3):221-230. https://doi.org/10.1626/pps.8.221

Descheemaeker K, Ronner E, Ollenburger M, Franke AC, Klapwijk CJ, Falconnier GN, Wichern J, Giller KE (2016) Which options fit best? Operationalizing the socio-ecological niche concept. Expl Agric:122. https://doi.org/10.1017/S001447971600048X

Devendra C, Sevilla CC (2002) Availability and use of feed resources in crop-animal systems in Asia. Agric Syst 71(1-2):59-73. https://doi. org/10.1016/S0308-521X(01)00036-1

Dimang S, Miranda P, Sophal L, Mom S, Stür WW, Savage D (2009) Improved cattle nutrition increases the time available for children of small-holder farmers in Cambodia to attend school. Rec Adv Anim Nutr 17:192

Fisher MJ, Rao IM, Ayarza MA, Lascano CE, Sanz JI, Thomas RJ, Vera RR (1994) Carbon storage by introduced deep-rooted grasses in the South American savannas. Nature 371(6494):236-238

Freitas DS, Rodak BW, dos Reis AR, Reis FB, de Carvalho TS, Schulze J, Carneiro MAC, Guilherme LRG (2018) Hidden nickel deficiency? Nickel fertilization via soil improves nitrogen metabolism and grain yield in soybean genotypes. Front Plant Sci 9:614. https://doi. org/10.3389/fpls.2018.00614

Fukai S, Ouk M (2012) Increased productivity of rainfed lowland rice cropping systems of the Mekong region. Crop Pasture Sci 63(10): 944-973. https://doi.org/10.1071/CP12294

Fukai S, Sittisuang P, Chanphengsay M (1998) Increasing production of rainfed lowland rice in drought prone environments. Plant Prod Sci 1: $75-82$

Gabunada FG Jr, Stür WW, Asis PT, Saguinhon J, Velasco C, Moneva LA, Magboo EC (2007) Adoption and use of forages in the uplands of the Visayas and Mindanao, Philippines. In: Hare MD, Wongpichet K (eds) Forages - A pathway to prosperity for smallholder farmers. Proceedings of a forage symposium, Ubon Ratchathani University, Thailand, 5-7 March 2007, pp 111-126

Hacker B, Novaha S, Phengvichith V (1998) Some natural and induced grasslands of the Lao PDR. In: Stür WW (ed) Proceedings of the third regional meeting of the Forages for Smallholders Project held at the Agency for Livestock Services of East Kalimantan, Indonesia. CIAT Working Document No. 188. Centro Internacional de Agricultura Tropical (CIAT), Vientiane, pp 167-172

Hare MD (2014) Village-based tropical pasture seed production in Thailand and Laos - a success story. Trop Grassl 2:165-174. https://doi.org/10.17138/TGFT(2)165-174

Hare MD, Tatsapong P, Lunpha A, Wongpichet K (2005) Brachiaria species in north-east Thailand: dry matter yields and seed production. Trop Grassl 39(2):99-106
Hin S, Bell RW, Newsome D, Seng V (2010) Understanding variability in texture and acidity among sandy soils in Cambodia. In: Gilkes RJ, Prakongkep N (eds) Proceedings 19th world congress of soil science: soil solutions for a changing world. Australian Society of Soil Science Incorporated, Brisbane, pp $50-53$

Hoang MT, Do TN, Nguyen TT, Hoang V, Hoang TTH, Chen W, Thai T, Qua LD, Mann S, Bell RW (2015a) Diagnosing multiple nutrient deficiencies that limit crop growth and yields on sands in south central coast of Vietnam. In: Mann S, Webb MC, Bell RW (eds) Sustainable and profitable crop and livestock systems for south-central coastal Vietnam. ACIAR Proceedings No. 143, pp 62-79

Hoang V, Hoang MT, Bell RW, Mann S, Do TN, Nguyen TT, Ho HC, Pham VB (2015b) Integrated nutrient management of annual and perennial crops on sandy coastal plains of south central coast of Vietnam. In: Mann S, Webb MC, Bell RW (eds) Sustainable and profitable crop and livestock systems for south-central coastal Vietnam. ACIAR Proceedings No. 143, pp 80-90

Horne PM, Stür WW (1999) Developing forage technologies with smallholder farmers - how to select the best varieties to offer farmers in Southeast Asia. ACIAR Monograph No. 62, ACIAR and CIAT

Inthavong T, Kam SP, Basnayake J, Fukai S, Linquist B, Monthathip C (2004) Using GIS technology to develop crop water availability maps for Lao PDR. In: Seng V, Creswell E, Fukai S, Fischer K (eds) Water in Agriculture. ACIAR Proceeding No. 116, pp 124-135

Inthavong T, Tsubo M, Fukai S (2011) A water balance model for characterization of length of growing period and water stress development for rainfed lowland rice. Field Crop Res 121(2):291-301. https://doi.org/10.1016/j.fcr.2010.12.019

Lathvilayvong P, Schiller JM, Phommasack T (1996) Soil limitations for rainfed lowland rice in Laos. In: Fukai S, Cooper M, Salisbury J (eds) Breeding strategies for rainfed lowland rice in drought prone environments. Proceedings of an international workshop held at Ubon Ratchathani, Thailand, 5-8 November 1996. ACIAR Proceedings No. 77, pp 74-90

Lefroy R, Collet L, Grovermann C (2010) Study on potential impacts of climate change on land use in the Lao PDR. Land Management and Registration Project (LMRP), International Center for Tropical Agriculture (Centro Internacional de Agricultura Tropical - CIAT), Vientiane

Lesturgez G, Poss R, Hartmann C, Bourdon E, Noble A, Ratana-Anupap S (2004) Roots of Stylosanthes hamata create macropores in the compact layer of a sandy soil. Plant Soil 260(1-2):101-109. https://doi.org/10.1023/B:PLSO.0000030184.24866.aa

Lesturgez G, Poss R, Noble A, Grünberger O, Chintachao W, Tessier D (2006) Soil acidification without $\mathrm{pH}$ drop under intensive cropping systems in Northeast Thailand. Agric Ecosyst Environ 114(2-4): 239-248. https://doi.org/10.1016/j.agee.2005.10.020

Lienhard P, Tivet F, Chabanne A, Dequiedt S, Lelièvre M, Sayphoummie S, Leudphanane B, Prévost-Bouré NC, Séguy L, Maron P-A, Ranjard L (2013) No-till and cover crops shift soil microbial abundance and diversity in Laos tropical grasslands. Agron Sustain Dev 33(2):375-384. https://doi.org/10. 1007/s13593-012-0099-4

Linquist B, Sengxue P (2001) Nutrient management of rainfed lowland rice in the Lao PDR. International Rice Research Institute, Los Banos

Mainuddin M, Kirby M (2009) Spatial and temporal trends of water productivity in the lower Mekong River basin. Agric Water Manag 96(11):1567-1578. https://doi.org/10.1016/j.agwat.2009.06.013

Manivong V, Cramb R, Newby J (2014) Rice and remittances: crop intensification versus labour migration in Southern Laos. Hum Ecol 42:367-379. https://doi.org/10.1007/s10745-014-9656-6 
Maxwell TW, Songly Y, Ung B, Peou L, Reid J (2012) The social and other impacts of a cattle/crop innovation in Cambodia. Agric Syst 107:83-91. https://doi.org/10.1016/j.agsy.2011.10.008

McRoberts KC, Ketterings QM, Parsons D, Hai TT, Quan NH, Ba NX, Nicholson CF, Cherney JR (2016) Impact of forage fertilization with urea and composted cattle manure on soil fertility in sandy soils of South-Central Vietnam. Int J Agron 2016:1-14. https://doi.org/10. 1155/2016/4709024

McRoberts KC, Parsons D, Ketterings QM, Hai TT, Quan NH, Ba NX, Nicholson CF, Cherney JR (2018) Urea and composted cattle manure affect forage yield and nutritive value in sandy soils of southcentral Vietnam. Grass Forage Sci 73:132-145. https://doi.org/10. $1111 /$ gfs. 12289

Millar J, Connell J (2010) Strategies for scaling out impacts from agricultural systems change: the case of forages and livestock production in Laos. Agric Hum Values 27(2):213-225. https://doi.org/10. 1007/s10460-009-9194-9

Millar J, Photakoun V (2008) Livestock development and poverty alleviation: revolution or evolution for upland livelihoods in Lao PDR? Int J Agric Sustain 6(1):89-102. https://doi.org/10.3763/ijas.2007.0335

Nakamanee G, Phaikaew C (1998) Seed production potential of Brachiaria species in northeast Thailand. In: Stür WW (ed) Proceedings of the third regional meeting of the Forages for Smallholders Project held at the Agency for Livestock Services of East Kalimantan, Indonesia. CIAT Working Document No. 188. Centro Internacional de Agricultura Tropical (CIAT), Vientiane, pp $155-162$

Nakamanee G, Srisomporn W, Phengsavanh P, Samson J, Stür W (2008) Sale of fresh forage - a new cash crop for smallholder farmers in Yasothon, Thailand. Trop Grassl 42(2):65-74

Nampanya S, Suon S, Rast L, Windsor PA (2012) Improvement in smallholder farmer knowledge of cattle production, health and biosecurity in Southern Cambodia between 2008 and 2010. Transbound Emerg Dis 59(2):117-127. https://doi.org/10.1111/j.1865-1682.2011.01247.x

Nesbitt HJ (1997) Topography, climate and rice production. In: Nesbitt HJ (ed) Rice production in Cambodia. International Rice Research Institute, Manila, pp 15-21

Noble AD, Gillman GP, Ruaysoongnern S (2000) A cation exchange index for assessing degradation of acid soil by further acidification under permanent agriculture in the tropics. Eur J Soil Sci 51:233243. https://doi.org/10.1046/j.1365-2389.2000.00313.x

Ojiem JO, de Ridder N, Vanlauwe B, Giller KE (2006) Socioecological niche: a conceptual framework for integration of legumes in smallholder farming systems. Int J Agric Sustain 4(1):79-93. https://doi. org/10.1080/14735903.2006.9686011

Ouerng C, Lim V, Christen E, Hornbuckle JW, Smith D, Zandoan R, Yin R, Mok S, Keo S (2013) Water use measurement using direct and indirect methods on a dry season rice crop. In: Smith D, Hornbuckle JW (eds) A literature review on rice productivity in Cambodia: constraints, challenges and options. Technical Report to ACIAR, Canberra, CSIRO Sustainable Agriculture Flagship, Australia

Pen M, Savage D, Stür W, Sophal L, Seng M (2010) Cattle feeding and management practices of small-holder farmers in Kampong Cham province, Cambodia. Int J Environ Rural Dev 1-1:132138

Peters M, Horne P, Schmidt A, Holman F, Kerridge PC, Tarawali SA, Schultze-Kraft R, Lascano CE, Argel P, Stür W, Fujisaka S, Müeller-Sämann K, Wortman C (2001) The role of forages in reducing poverty and degradation of natural resources in tropical production systems. Agricultural Research and Extension Network Paper No. 117. Overseas Development Institute, London

Pheav S, Bell RW, White PF, Kirk GJD (2003) Fate of applied fertilizer phosphorus in a highly weathered sandy soil under lowland rice cropping, and its residual effect. Field Crop Res 81(1):1-16. https://doi.org/10.1016/S0378-4290(02)00191-0

Pheav S, Bell RW, White PF, Kirk GJD (2005) Phosphorus mass balances for successive crops of fertilised rainfed rice on a sandy lowland soil. Nutr Cycl Agroecosyst 73(2-3):277-292. https://doi.org/10.1007/ s10705-005-3820-8

Phengpet S, Hare M, Terapongtanakorn S, Wongpichet K (2016) Effect of waterlogging on morphological changes and growth of six forage grasses. Khon Kaen Agric J 44(2):363-372

Phengsavanh P, Phimphachanhvongsod V (1998) Environmental adaptation of forages in Lao PDR. In: Stür WW (ed) Proceedings of the third regional meeting of the Forages for Smallholders Project held at the Agency for Livestock Services of East Kalimantan, Indonesia. CIAT Working Document No. 188. Centro Internacional de Agricultura Tropical (CIAT), Vientiane, pp 41-52

Phengsavanh P, Phimphachanhvongsod V (2007) Forage development in Lao PDR: emerging impacts from planted forages in the upland of Lao PDR. In: Hare MD, Wongpichet K (eds) Forages - A pathway to prosperity for smallholder farmers. Proceedings of a forage symposium, Ubon Ratchathani University, Thailand, 5-7 March 2007, pp 263-269

Phengsouvana V, Attanandana T, Russell S, Yost RS (2009) Lime application to two acidic upland soils for soybean production in Champasak Province, Lao PDR. Kasetsart J (Nat Sci) 43:19-27

Philp J, Komarek AM, Pain SJ, Li X, Bellotti W (2016) Improving the use of available feed resources to overcome sheep feeding deficits in western China. Anim Prod Sci 56(9):1545-1550. https://doi.org/10. 1071/AN14694

Philp J, Komarek AM, Pain SJ, Bellotti W (2017) Variation in feed utilisation by sheep undergoing compensatory growth following underfeeding with and without additional dietary nitrogen in western China. Anim Prod Sci 57(1):96-101. https://doi.org/10.1071/ AN15185

Phimphachanhvongsod V, Phengsavanh P (1998) Developing and evaluating forage technologies with farmers in Lao PDR. In: Stür WW (ed) Proceedings of the third regional meeting of the Forages for Smallholders Project held at the Agency for Livestock Services of East Kalimantan, Indonesia. CIAT Working Document No. 188. Centro Internacional de Agricultura Tropical (CIAT), Vientiane, pp $129-137$

Pinkerton A, Smith FW, Lewis DC (1997) Pasture species. In: Reuter DJ, Robinson JB (eds) Plant analysis: an interpretation manual. CSIRO Publishing, Melbourne, pp 287-346

Pizarro EA, Hare MD, Mutimura M, Bai C (2013) Brachiaria hybrids: potential, forage use and seed yield. Trop Grassl 1:31-35. https:// doi.org/10.17138/TGFT(1)31-35

Ragland J, Boonpuckdee L (1987) Fertiliser responses in Northeast Thailand: 1. Literature review and rationale. Thai J Soil Fert 9:65-79

Rao IM, Kerridge PC, Macedo MCM (1996) Nutritional requirements of Brachiaria and adaptation to acid soils. In: Miles JW, Maass BL, Valle CB (eds) Brachiaria: biology, agronomy, and improvement. Centro Internacional de Agricultura Tropical (CIAT), Cali, pp 53-71

Rao I, Peters M, Castro A, Schultze-Kraft R, White D, Fisher M, Miles J, Lascano C, Blummel M, Bungenstab D, Tapasco J, Hyman G, Bolliger A, Paul B, Van Der Hoek R, Maass B, Tiemann T, Cuchillo M, Douxchamps S, Villanueva C, Rincón Á, Ayarza M, Rosenstock T, Subbarao G, Arango J, Cardoso J, Worthington M, Chirinda N, Notenbaert A, Jenet A, Schmidt A, Vivas N, Lefroy R, Fahrney K, GuimarÃEs E, Tohme J, Cook S, Herrero M, ChacÓN M, Searchinger T, Rudel T (2015) LivestockPlus: the sustainable intensification of forage-based agricultural systems to improve livelihoods and ecosystem services in the tropics. Trop Grassl 3:59-82. https://doi.org/10.17138/TGFT(3)59-82 
Rudel TK, Paul B, White D, Rao IM, Van Der Hoek R, Castro A, Boval M, Lerner A, Schneider L, Peters M (2015) LivestockPlus: forages, sustainable intensification, and food security in the tropics. Ambio 44(7):685-693. https://doi.org/10.1007/s13280-015-0676-2

Samkol P, Sath K, Patel M, Windsor PA, Holtenius K (2015) Survey of smallholder beef cattle production systems in different agro-ecological zones of Cambodia. Trop Anim Health Prod 47(7):1299-1306. https://doi.org/10.1007/s11250-0150863-y

Seng V, Ros C, Bell RW, White PF, Hin S (2001) Nutrient requirements of rainfed lowland rice in Cambodia. In: Fukai S, Basnayake J (eds) Increased Lowland Rice Production in the Mekong Region. ACIAR Proceedings 101

Seng V, Bell RW, White PF, Schoknecht N, Hin S, Vance W (2005) Sandy soils of Cambodia. In: Proceedings of the first international conference on the management of tropical sandy soils. Khon Kaen, Thailand, Nov 2005 (CD-ROM)

Seng V, Bell RW, Willett IR (2006) Effect of lime and flooding on phosphorus availability and rice growth on two acidic lowland soils. Commun Soil Sci Plant Anal 37:313-336. https://doi.org/10.1080/ 00103620500439824

Seng V, Bell RW, White PF, Schoknecht N, Hin S, Vance W (2007) Sandy soils of Cambodia. In: Management of Tropical Sandy Soils for Sustainable Agriculture. Symposium on the Management of Tropical Sandy Soils, Khon Kaen, Thailand, Nov 2005. FAO regional Office for Asia and the Pacific, Bangkok. pp 42-48

Seng V, Bell RW, Hin S, Schoknecht N, Vance W, White PF (2009) Soil factors affecting crop suitability for upland crops in Cambodia. Cambodian J Agric 9:24-37

Sharma PK, Ingram KT, Harnpitchitvitaya D (1995) Subsoil compaction to improve water use efficiency and yields of rainfed lowland rice in coarse textured soils. Soil Tillage Res 36(1-2):33-44. https://doi. org/10.1016/0167-1987(95)00499-8

Sitthaphanit S, Limpinuntana V, Toomsan B, Panchaban S, Bell RW (2009) Fertiliser strategies for improved nutrient use efficiency on sandy soils in high rainfall regimes. Nutr Cycl Agroecosyst 85(2): 123-139. https://doi.org/10.1007/s10705-009-9253-Z

SSLCC (1996) Soil physical and chemical properties analysis for soil of Lao PDR. Soil Survey and Land Classification Center, Vientiane

Stür WW, Cameron AG, Hacker JB (1995) Forages for smallholders. Proceedings of the third meeting of the Southeast Asian forage seeds project, Samarinda, Indonesia, 23-28 October 1994. CIAT Working Document No. 143, CIAT, Cali, Colombia

Stür WW, Hopkinson JM, Chen CP (1996) Regional experience with Brachiaria: Asia, the South Pacific and Australia. In: Miles JW, Maass BL, do Valle CB (eds) Brachiaria: biology, agronomy and improvement. CIAT, Cali, pp 258-271

Stür WW, Ibrahim T, Tuhulele M, Binh LH, Gabunada F Jr, Ibrahim NG, Phimphachanhvongsod V, Liu G, Horne PM (2000) Adaptation of forages to climate, soils and use in smallholder farming systems in Southeast Asia. In: Stür WW, Horne PM, Hacker JB, Kerridge PC (eds) Working with farmers: the key to adoption of forage technologies. ACIAR Proceedings No. 95. ACIAR, Canberra, pp 112-119

Stür WW, Horne PM, Gabunada FA Jr, Phengsavanh P, Kerridge PC (2002) Forage options for smallholder crop-animal systems in Southeast Asia: working with farmers to find solutions. Agric Syst 71(1-2):75-98. https://doi.org/10.1016/S0308-521X(01) 00037-3

Stür WW, Horne PM, Phengsavanh P, Gabunada F, Khanh TT, Connell J (2007) Planted forages - the key for making money from smallholder livestock production: experiences from CIAT's forage R\&D in Southeast Asia. In: Hare MD, Wongpichet K (eds) Forages - a pathway to prosperity for smallholder farmers. Proceedings of a forage symposium,
Ubon Ratchathani University, Thailand, 5-7 March 2007, pp 313-331

Stür W, Khanh TT, Duncan A (2013) Transformation of smallholder beef cattle production in Vietnam. Int J Agric sustain 11(4):363-381. https://doi.org/10.1080/14735903.2013.779074

Sumberg J (2002) The logic of fodder legumes in Africa. Food Policy 27(3):285-300. https://doi.org/10.1016/S0306-9192(02)00019-2

Teluguntla P, Thenkabail PS, Xiong J, Gumma MK, Giri C, Milesi C, Ozdogan M, Congalton RG, Tilton J, Sankey TT, Massey R, Phalke A, Yadav K (2016) Global food security support analysis data at nominal $1 \mathrm{~km}$ (GFSAD1 km) derived from remote sensing in support of food security in the twenty-first century: current achievements and future possibilities. In: Thenkabail PS (ed) Land resources monitoring, modeling, and mapping with remote sensing. CRC Press, Boca Raton, pp 131-160

Thoeun HC (2015) Observed and projected changes in temperature and rainfall in Cambodia. Weather Clim Extrem 7:61-71. https://doi.org/ 10.1016/j.wace.2015.02.001

Tiemann T, Khamphoumee S, Phimphachanhvongsod V (2014a) Developing improved farming and marketing systems in rainfed regions of southern Lao PDR (forage-livestock subproject). In: Robins L (ed) A policy dialogue on rice futures: rice-based farming systems research in the Mekong region. Australian Centre for International Agricultural Research, Canberra, pp 68-72 Retrieved from http://aciar.gov.au/ publication/pr142. Accessed 29 Aug 2017

Tiemann T, Khamphoumee S, Phimphachanhvongsod V (2014b) Lessons from forage based livestock interventions requiring a farm systems change. Lao J Agri Forest. April:80-84

Tuhulele M, Ibrahim H, Tugiman TM, Heriadi A, Hasyim S, Ibrahim T, Hutasoit R, Radianto TZ, Zainal G, Mansur BT, Susilan LI (1998) Farmer evaluation of forages in Indonesia: progress, experiences and future plans. In: Stür WW (ed) Proceedings of the third regional meeting of the Forages for Smallholders Project held at the Agency for Livestock Services of East Kalimantan, Indonesia. CIAT Working Document No. 188. Centro Internacional de Agricultura Tropical (CIAT), Vientiane, pp 146-153

Tuhulele M, Taufiq, Hariadi A, Hasim S, Fathoni, Aldrin M, Stür WW (2007) Adoption of Brachiaria humidicola by smallholder farmers in Central Kalimantan, Indonesia. In: Hare MD, Wongpichet K (eds) Forages - a pathway to prosperity for smallholder farmers. Proceedings of a forage symposium, Ubon Ratchathani University, Thailand, 5-7 March 2007, pp 297-312

Vance W, Bell RW, Seng V (2004) Rainfall analysis for the provinces of Battambang, Kampong Cham and Takeo, the Kingdom of Cambodia. Report for ACIAR Project LWR1/2001/051

Vendramini JMB, Sollenberger LE, Soares AB, Da Silva WL, Sanchez JMD, Valente AL, Aguiar AD, Mullenix MK (2014) Harvest frequency affects herbage accumulation and nutritive value of Brachiaria grass hybrids in Florida. Trop Grassl 2(2): 197-206. https://doi.org/10.17138/TGFT(2)197-206

Vial LK, Lefroy RDB, Fukai S (2013) Effects of hardpan disruption on irrigated dry-season maize and on subsequent wet-season lowland rice in Lao PDR. Field Crop Res 152:65-73. https://doi.org/10. 1016/j.fcr.2013.06.016

Wade LJ, Fukai S, Samson BK, Ali A, Mazid MA (1999) Rainfed lowland rice: physical environment and cultivar requirements. Field Crop Res 64:3-12. https://doi.org/10.1016/S03784290(99)00047-7

White PF, Oberthür T, Pheav S (1997a) The soils used for rice production in Cambodia: a manual for their identification and management. International Rice Research Institute, Manila 
White PF, Oberthur T, Pheav S (1997b) Soils and rice. In: Nesbitt HJ (ed) Rice production in Cambodia. International Rice Research Institute, Manila, pp 21-29

White DW, Peters M, Horne P (2013) Global impacts from improved tropical forages: a meta-analysis revealing overlooked benefits and costs, evolving values and new priorities. Trop Grassl 1:12-24. https://doi.org/10.17138/TGFT(1)12-24

Wong M, Swift R (2003) Role of organic matter in alleviating soil acidity. In: Rengel Z (ed) Handbook of soil acidity. Marcel Dekker, New York, pp 337-358

Workman DR (1972) Geology of Laos, Cambodia, South Vietnam and the eastern part of Thailand: a review. Institute of Geological Sciences, London
Young JR, O'Reilly RA, Ashley K, Suon S, Leoung IV, Windsor PA, Bush RD (2014) Impacts on rural livelihoods in Cambodia following adoption of best practice health and husbandry interventions by smallholder cattle farmers. Transbound Emerg Dis 61(Suppl 1):11-24. https://doi.org/10.1111/tbed.12193

Publisher's note Springer Nature remains neutral with regard to jurisdictional claims in published maps and institutional affiliations. 